\title{
Fesztiválok gazdasági hatáselemzése
}

Tanulmányunk nyolc - 2017-ben és 2018-ban megrendezett, néhány tíz milliótól több száz millió forintosig terjedő költségvetésü - magyarországi fesztivál gazdasági hatásainak összehasonlító elemzését mutatja be. A szervezők költségvetési adatait számítógépes ürlapokkal és mélyinterjúkkal vettük fel, a fesztivállátogatói költéseket helyszíni, személyes megkérdezésen alapuló, kérdőíves felmérésekkel vizsgáltuk. A hatáselemzést országos és regionális input-output táblákkal és multiplikátorokkal végeztük. A nyolc fesztivál együttes országos hozzáadottértékhatása meghaladja az 1,6 milliárd forintot, teljes munkaidejü egyenértékes létszámmal számított foglalkoztatási hatásuk 400-450 fö körüli, a szociális hozzájárulási adót és egyéni járulékokat, személyi jövedelemadót és nettó termékadókat is magában foglaló adóhatásukat pedig 1,1-1,2 milliárd forintra becsüljük. Az egyedi hatáselemzések eredményeinek általánosításával kimutatjuk, hogy a Magyar Fesztivál Szövetségnél nyilvántartott, közel 300 fesztivál nemzetgazdasági jelentősége a teljes utazásszervezés, utazásközvetítés ágazatéhoz hasonló.* Journal of Economic Literature (JEL) kód: C67, L83, Z31.

\footnotetext{
* A tanulmány az EFOP-3.6.1-16-2016-00012 kódszámú, Innovatív megoldásokkal Zala megye $\mathrm{K}+\mathrm{F}+\mathrm{I}$ tevékenysége hatékonyságának növeléséért címü projekt keretében, annak támogatásával készült. Köszönettel tartozunk továbbá a vizsgált fesztiválok szervezőinek és kérdőíves felméréseinkben részt vett látogatóinak értékes válaszaikért, Szabari Péternének és Simor Máté Péternek (KSH Nemzeti Számlák Főosztály), a fesztiválszakma képviselőinek, valamint a kutatócsoport tagjainak a gondolkodásunkat segítő konzultációkért. Hálásak vagyunk a tanulmány lektorának a kézirathoz füzött hasznos észrevételeiért, módosítási, kiegészítési javaslataiért. Ezeket is igyekeztünk megfogadni és beépíteni a végleges változatba.
}

Koppány Krisztián egyetemi docens, Széchenyi István Egyetem Kautz Gyula Gazdaságtudományi Kar; tudományos főmunkatárs, Budapesti Gazdasági Egyetem Pénzügyi és Számviteli Kar (e-mail: koppanyk@sze.hu).

Solt Katalin professzor emerita, Budapesti Gazdasági Egyetem (e-mail: solt.katalin@uni-bge.hu).

Hunyadi Zsuzsanna tudományos munkatárs, Budapesti Gazdasági Egyetem (e-mail: hunyadi. zsuzsanna@uni-bge.hu).

A kézirat első változata 2020. január 10-én érkezett szerkesztőségünkbe.

DOI: http://dx.doi.org/10.18414/KSZ.2020.6.585 


\section{Bevezetés}

Az elmúlt években mindannyian tapasztalhattuk, hogy országszerte gombamódra szaporodnak a fesztiválnak nevezett rendezvények. Tavasztól őszig minden hétvégén számos programra kerül sor. Az ezek iránti érdeklődést jól mutatja egy reprezentatív felmérés (Sulyok [2010]), amely szerint a lakosság már az előző évtized végén is nagy arányban vett részt ilyen rendezvényeken. A fesztiválok látogatása fontos kulturális, szórakozási formává vált.

Az ágazat méretéről, gazdasági jelentőségéről mindezek ellenére csak meglehetősen kevés és egymásnak ellentmondó információink vannak. A fesztiválturizmus nem szerepel külön soron egyetlen statisztikában sem. A gazdasági tevékenységek egységes ágazati osztályozási rendszerében (TEÁOR) sincs külön fesztiválszervezési tevékenység. A fesztiválokról egységes, hiteles és teljes körü nyilvántartást valójában senki sem vezet. Természetesen léteznek különféle felmérések, becslések - ezekre a későbbiekben részletesebben is kitérünk. A Magyar Fesztivál Szövetség is működtet egy önkéntes regisztráción alapuló minősítési programot, amelynek adatbázisa talán a legtöbb adatot tartalmazza az egyes fesztiválokról. Tanulmányunkban mi is erre támaszkodunk. Ebben azonban korántsem szerepel minden rendezvény. Az ágazat nagyságával kapcsolatban tehát meglehetősen nagy a bizonytalanság. Még a fesztiválok számára vonatkozó, különböző forrásokból származó információk is nagyságrendi eltéréseket mutatnak.

A kutató közgazdász számára mindig inspiráló olyan jelenségek vizsgálata, amelyekkel kapcsolatban tudásunk hiányos, amelyek gazdasági értékének kifejezésére nem állnak rendelkezésre a szokásos mérőszámok. Bár nem a fesztiválszámbecslés egy újabb módszerének kidolgozását vagy a rendezvények egységes nyilvántartási rendszerének kidolgozását tűztük ki célul (utóbbi inkább szabályozói szándék és döntés kérdése), kutatásunkat mégis leginkább az ösztönözte, hogy hozzájáruljunk az ágazat méretét és teljesítményét övezö bizonytalanság csökkentéséhez. A témafelvetés elsőként magának a szakmának, egy később a kutatásban is részt vevő fesztiválszervezőnek a részéről fogalmazódott meg: próbáljuk meg számszerűsíteni a fesztiválok nemzetgazdasági hatásait!

A kérdés az egyes fesztiválok és a teljes ágazat szintjén is érdekes. Tudomásunk szerint Magyarországon még nem készültek (legalábbis nyilvánosságra nem kerültek) - leszámítva a legnagyobb rendezvényeket - egységes módszertannal készített, egymással összemérhető eredményeket felmutató gazdasági hatáselemzések egyedi fesztiválokra, különösen több, területileg, tematika, méret és szervezö szerint különböző rendezvényekből álló „mintára”. A kis- és közepes fesztiválok szervezői rendszerint nincsenek tisztában rendezvényeik gazdasági hatásaival. Az ő támogatásukban is bízva olyan kutatási tervet fogalmaztunk meg, amely többek között magában foglalta a hazai fesztiválok gazdasági hatáselemzésére alkalmas egységes vizsgálati eljárás kidolgozását $s$ ennek több fesztiválon történő alkalmazását is. A kutatás megvalósítására pályázati támogatással egy hároméves, összesen 14 fesztiválra kiterjedő projektet sikerült létrehoznunk, amelyben a fesztiválszervezés gyakorlatát kiválóan ismerő szakemberek és a gazdasági mérési eszközök 
alkalmazásában tapasztalatot szerzett kutatók működtek közre a megfogalmazott cél elérése érdekében.

A kidolgozott eljárás újszerüsége elsősorban nem az alkalmazott módszerekben, hanem ez előbb említett egységes szemléletben, a nemzetgazdasági elszámolás rendszerével való kompatibilitásában, a módszerek teljeskörűségre, aggregált kategóriák helyett részletes bevételi és kiadási struktúrákra történő, aprólékos alkalmazásában rejlik. Adataink a közönség és a fesztiválszervezők kiadásainak, bevételeinek és ráfordításainak kérdőíves, illetve számítógépes ürlapokkal és szakmai konzultációkkal támogatott lekérdezésén alapulnak. A fesztiválokhoz kapcsolható közvetlen kiadások adataiból input-output módszer segítségével becsüljük meg a gazdaság más szektoraira is tovagyürüző, közvetett hatásokat.

Az input-output multiplikátorokkal történő hatáselemzést - széles körü alkalmazása ellenére - számos kritika éri (lásd például Diedering-Kwiatkowski [2015], Dwyer és szerzőtársai [2016]). A kapott eredmények megfelelő értelmezésével azonban könnyen elejét vehetjük az ellenérveknek, amelyek leggyakrabban a fesztiválokon jelentkező kiadások természetével kapcsolatosak. Teremt-e új keresletet egy fesztivál? Vagy csak kiadásokat csoportosít át? Ezt a vizsgálat területi lehatárolása is nagyban befolyásolja. Természetesen előfordulhat, hogy egy kisebb méretü, más térségek számára kisebb vonzerejű rendezvény nagyrészt inkább csak a helyi közönség hasonló vagy más célokra talán amúgy is helyben elkölteni kívánt kiadásait csoportosítja át. Más a helyzet a régión kívülről érkező, a térség végső keresletét várhatóan nem csökkentö költekezésekkel, a fesztivál által generált belföldi, esetleg külföldi turisztikai bevételekkel. S az is számít, hogy a látogatók és a szervezők által elköltött pénzekből mekkora mértékű a beszállítói értékláncokon, külső megrendeléseken keresztül történő elszivárgás.

Bárhogy is nézzük azonban, ha egy már megvalósult fesztiválhoz kapcsolódóan költekezés történt, akkor annak közvetlen és kisebb-nagyobb multiplikatív hatásai is jelentkeztek, amelyek benne vannak az ország vagy a vizsgált régió gazdasági teljesítményében. Még akkor is, ha a hivatalos statisztika elkülönülten nem mutatja ki ezeket, s nem rendeli hozzá a fesztiválágazathoz. A fesztiválok és az azokon megfordult látogatók számának, az általuk megvalósult költekezésnek, a rendezvények költségvetéseinek, valamint az ezekhez nyújtott állami, központi és helyi kormányzati támogatásoknak a növekedése viszont egyre inkább azt indokolja, hogy - a fesztiválokat és szervezésüket egyfajta gazdasági tevékenységként, ágazatként kezelve - tisztábban lássuk az országos és a regionális gazdaság teljesítményéhez való hozzájárulásukat, nemzetgazdasági, területi és turisztikai hozzáadottérték- és foglalkoztatási hatásukat s az általuk generált adóbevételek nagyságát.

Tanulmányunkban az erre a célra kidolgozott elemzési keretünket és az ennek alkalmazásával kapott eredményeinket mutatjuk be. ${ }^{1}$ Rövid szakirodalmi áttekintést

\footnotetext{
${ }^{1}$ Részeredményeinkről konferencia-előadások és egy rövidebb tanulmány formájában már korábban is beszámoltunk (Koppány [2018a], [2019], Solt és szerzőtársai [2018], [2019]). Mostani írásunk több ponton támaszkodik ezekre a már meglévő anyagokra. Ez az előzőkhöz képest jelentősen átdolgozott és kibővített tanulmány azonban már a lezárt kutatás összes hatáselemzési eredményét magában foglalja és szintetizálja.
} 
adunk, amelynek keretében megtesszük a szükséges fogalmi meghatározásokat, $s$ részletesebben kifejtjük a bevezetés elején jelzett bizonytalanságokat és ellentmondásokat. Kitérünk a fesztiválok gazdasági hatáselemzésére, valamint a szakirodalomban alkalmazott módszerekre is, s indokoljuk a választott metódus melletti döntésünket.

Ezt az alkalmazott vizsgálati eljárás részletes tárgyalása követi: a fesztiválok által generált bevételek és kiadások körének meghatározása, ezek számbavételének technikái, input-output modellkeretbe helyezésük, a tovagyürüző hatások számszerűsítéséhez használt országos és regionális multiplikátorok alkalmazása, a piaci árról alapárra (a termelő által realizált árra) való áttérés, a piaci és nem piaci termelés kérdése.

A projekt során vizsgált tizennégy fesztivál közül végül rendelkezésre álló adataink csak nyolc esetben tették lehetővé a teljes körű gazdasági hatáselemzést. Ennek a nyolc fesztiválnak a bevételeit, látogatóinak költését, termelöfelhasználását, országos és regionális hozzáadottérték-, foglalkoztatási, adóhatásaikat és rendezvényszintü multiplikátoraikat hasonlítjuk össze. ${ }^{2}$ Kimutatjuk a fesztiválok együttes hatásait is.

Ezek után a felmért nyolc fesztiválra vonatkozó eredményeink egyfajta általánosításának, a fesztiválszektorra való kiterjesztésének lehetőségét mutatjuk be. A fesztiválok költségvetése és a multiplikátorok között feltárt összefüggést a Magyar Fesztivál Szövetségnél regisztrált, értelmezhető költségvetési adattal nyilvántartott fesztiválokra alkalmazva, becslést adunk a közel 300 rendezvény együttes hozzáadottérték- és foglalkoztatási hatására, majd ez alapján elhelyezzük a szektort a magyar gazdaság ágazatai között.

A tanulmányt az eredmények összefoglalása zárja. A módszertan bemutatásának matematikai részleteit a Függelékben, a nagy táblázatokat pedig az online elérhetö Mellékletben helyeztük el. ${ }^{3}$

\section{Szakirodalmi áttekintés}

\section{Fogalmi meghatározás}

A nemzetközi szakirodalomban fellelhető definíciók szinte mindegyike Donald Getz írásaira vezethető vissza, aki alapító főszerkesztője volt a Festival Management \& Event Tourism címü folyóiratnak, amely ma Event Management címen jelenik meg, s a témakör legjelentősebb szakmai fórumai közé tartozik. Getz [2005] definíciója szerint a fesztivál „tematikus nyilvános ünnep” (22. o.). Egy másik, a fesztiválokkal

\footnotetext{
${ }^{2}$ A kutatási eredmények publikálása során szigorúan tartjuk magunkat a vállalt anonimitáshoz, így az ábrákon és táblázatokban megjelenő fesztiváladatok és elemzési eredmények név nélkül, csupán egy betűkóddal és a fesztivál jellegére utaló jelzővel, a konkrét beazonosítást jelentősen korlátozva jelennek meg.

${ }^{3}$ A Melléklet a http://www.sze.hu/ koppanyk/web/public/Kszemle2020/Fesztivalok_gazdasagi_ hataselemzese_Koppany_et_at_ELEKTRONIKUS_MELLEKLET.pdf linken érhető el.
} 
foglalkozó szakirodalmi áttekintés definíciója ehhez nagyon hasonló, de magában foglalja a rendezvény ismétlődő, időszakonként visszatérő jellegét is: a fesztivál „nyilvános tematikus ünnep, amelyet rendszeresen rendeznek meg" (Wilson és szerzőtársai [2017] 4. o.). A fesztiválok meghatározásánál a tanulmányban ez utóbbi megközelítést alkalmazzuk.

A Magyar Fesztivál Szövetség a következö, még részletesebb meghatározást adja:

„Fesztiválnak nevezhető minden olyan - egy vagy több téma köré szerveződő, rendszeresen megrendezésre kerülö, egy vagy több helyszínen zajló, meghirdetett programmal rendelkező - kulturális, művészeti, gasztronómiai, sport vagy egyéb eseménysorozat, amelynek célja, hogy közönsége részére kiemelten színvonalas, értékközvetítő, minőségi ismereteket is bővitő és egyben szórakoztató, szabadidős közösségi élményt nyújtson." (www.fesztivalszovetseg.hu.)

A hazai fesztiválok számbavétele során bármelyik fenti meghatározást (akár a legtágabb értelmezést) alkalmaztuk is, akkor sem találtunk igazán megbízható adatokat. Erős kétkedéssel fogadtuk azt az információt, hogy 2014-ben Magyarországon a Magyar Turizmus Zrt. nemzeti turisztikai adatbázisában (NETA) 3328 magyarországi fesztivált regisztráltak (Sulyok [2016]). Természetesen nem az adatbázis megbízhatóságában kételkedtünk, hanem a kapott eredmény hitelességében: tényleg ennyi fesztivál lenne évente Magyarországon? Más adatok ugyanis ennél jóval kisebb értékeket mutattak. Egy 2016-os kutatás során 1626 önkormányzat megkérdezése alapján 308 fesztivált jeleztek (Fesztiválkutatás [2016]). Ugyanebben az évben a Magyar Fesztivál Szövetségnek 216 regisztrált tagja volt (MFSZ [2017]). Ha a kutatás más eredményeit is számításba vesszük, s megnézzük, hogy például egyes támogatási formákra hány kérelmet nyújtottak be, akkor sem találnánk ezernél több olyan rendezvényt, amelyet fesztiválnak minősíthetünk (lásd Fesztiválkutatás [2016]). ${ }^{4}$

Sajnos a Központi Statisztikai Hivatal (KSH) adatai sem - vagy csak nagyon töredékesen és közvetve - tartalmaznak információt a fesztiválokra vonatkozóan. A turisztikai felmérésekben időnként megkérdezik az utazás célját, illetve a közmüvelödési intézmények tevékenységei között - sok más egyéb rendezvénnyel összevontan - szerepelnek a fesztiválok is. A fesztiválturizmus azonban nem szerepel külön soron egyetlen statisztikában sem, legfeljebb tájékoztató anyagokban találunk becsléseket erre vonatkozóan. Ez nem véletlen, mert a fesztiválok a turizmusvendéglátás körben is nagyon sajátos helyzetben vannak. A fesztiválok mint szolgáltatások fogyasztói egy „összetett terméket” fogyasztanak, amely különböző műsorokból (kulturális, zenei, színházi stb.), egyéb szórakoztató programokból (játékok, foglalkoztatók), illetve vendéglátóipari és egyéb kiskereskedelmi szolgáltatásokból áll. A terméket pedig nem egyetlen eladó kínálja, hanem szinte minden típusát más és más cégek, szervezetek. Így nem lehet egyetlen gazdálkodó szervezet adatai alapján végezni a felmérést. Mindezt tovább bonyolítja, hogy egyes szolgáltatók nem is

\footnotetext{
${ }^{4} \mathrm{Az}$ állami támogatások elemzése során 1100 kérelmet találtak, de ezekben is sok átfedés van, mert egy-egy fesztivál több helyre is pályázhatott. Így a vizsgálat a kérelmek számát ugyan feltárta, de azt nem állapította meg, hogy ezek hány fesztiváltól érkeztek. Vannak fesztiválok, amelyek akár tízféle állami forrásból, helyről is kapnak támogatást, sok van, amelyik négy-öt helyről.
} 
a helyszínhez kötötten működnek, hanem úgynevezett vásározók, akik hétről hétre máshol állítják fel sátraikat, standjaikat, kínálják az ételt, italt, ajándéktárgyakat. Egyetlen viszonylag könnyen elérhető szereplő van, a fesztiválszervező, aki viszont a szolgáltatásoknak csak egy részét kínálja, ráadásul, ahogy ezt a később bemutatásra kerülő elemzési eredményeink is alátámasztják, közvetlenül, piaci termelöként általában nem termel pozitív hozzáadott értéket, csak a kapcsolódó beszállítók és egyéb szolgáltatók tevékenységét is figyelembe véve. Ilyen értelemben akár el is fogadható, hogy a fesztiválszervezés mint önálló gazdasági tevékenység statisztikai megkülönböztetése nem indokolt.

A tartósan veszteséges gazdálkodó szervezetek hivatalos értékelése természetesen nem piaci termelőként történik, így a hozzáadott érték negativitásának problémája ágazati szinten rendszerint nem áll fenn, különösen nem az állami, kormányzati szektorban (az ide tartozó vállalatok, szervezetek hozzáadott értéke definíció szerint nem lehet negatív). A fesztiválok jelentős része önkormányzatok, kultúrházak, nonprofit szervezetek által szervezett ingyenes rendezvény, amelyen a látogatóknak nem kell belépődijat fizetniük. ${ }^{5}$ (Az ezen felüli fogyasztás már természetesen nem ingyenes, mint ahogyan az odajutás, esetleg szállás igénybevétele is költségekkel jár.) Egy ilyen programszervezet teljesítményét így még csak részlegesen sem lehet piaci bevételeinek a figyelembevételével mérni, hanem csak a kiadásai, ráfordításai alapján. (Mi is így fogunk tenni, s a piaci és nem piaci termelőként való számbavétel kérdésére is visszatérünk majd.)

\section{Fesztiválok hatáselemzésének módszerei}

Az 1980-as években nemzetközi méretekben még csak évente néhány szaktanulmány foglalkozott ezzel a témával, de mára speciális folyóiratokban, kiemelkedő hivatkozási adatokkal rendelkező tanulmányokra bukkanhatunk. Wilson és szerzőtársai [2017] vizsgálata szerint az általuk elemzett 35 év szakmai termésének csaknem fele a 2010-es években keletkezett. Az egy évre jutó átlagos publikációk száma a 2000 -es években még nem érte el a hatot, a 2010-es években pedig már tíz fölé növekedett. A tanulmányok többsége (93 százaléka) empirikus kutatást mutat be, csak néhány elméleti jellegű munkát olvashatunk a témáról. A fesztiválokkal foglalkozó szakirodalomra az is jellemző, hogy több mint 60 százaléka kvantitatív módszert alkalmazott, 20 százaléka kvalitatív elemzést végzett, a többi pedig kevert módszerrel dolgozott.

A tanulmányok egyik kiemelt témája a fesztiválok hatásainak vizsgálata. A kutatók azzal érvelnek az ilyen típusú vizsgálatok mellett, hogy az eredmények - a fesztiválokból származó hasznok kimutatásával - a szervezők számára indokokat adnak a helyi önkormányzat és más szponzorok támogatásának megnyeréséhez. Jellemző például Jackson és szerzötársai [2005] magyarázata, miszerint egy fesztivál gazdasági

\footnotetext{
${ }^{5}$ A Magyar Fesztivál Szövetség adatai szerint a náluk 2017-ben regisztrált 314 fesztiválon 4,8 millió látogató járt, akik közül csak 1,1 millió fizetett belépődíjat (MFSZ [2017], [2019]).
} 
hatásának mérése fontos eleme a döntéshozatalnak a támogatók, a beruházók, valamint a kormányzati szervek számára is.

Getz [2010] az angol nyelvű tudományos munkák között 423 fesztiválkutatással kapcsolatos tanulmányt talált és dolgozott fel. A cikkek több mint fele rendezvénytervezéssel és menedzsmenttel foglalkozott, a második legnépszerübb téma (a dolgozatok mintegy 30 százalékában) a fesztiválok hatásainak vizsgálata volt.

Kim és szerzőtársai [2013] kutatása a fesztiváloknál tágabb témakörre terjedt ki. A szerzők az összes rendezvénnyel foglalkozó tanulmányt elemezték. ${ }^{6}$ Vizsgálatukban megjelentek például a sportrendezvények is (ezekkel foglalkozott az általuk áttekintett 178 tanulmány 23 százaléka). A vizsgálatba bevont cikkek negyede tanulmányozta a rendezvények hatásait. Ez az átlagos arány a vizsgált harminc év alatt viszonylag stabil, s a kutatás tárgyát tekintve mindvégig a legmagasabb volt. Tanulmányunk célja - a fesztiválok nemzetgazdasági teljesítményhez való hozzájárulásának elemzése - ily módon beletartozik a fesztiválkutatások nemzetközi föirányába.

A fesztiválok gazdasági hatáselemzésének módszereit sokféle szempontból lehet csoportosítani és vizsgálni (lásd például Kundi [2012] vagy Brávácz [2019]). Tanulmányunk számára elsősorban azok a módszerek érdekesek, amelyek a makrogazdasági vagy regionális teljesítmény meghatározására alkalmasak. Ebből a szempontból Jackson és szerzőtársai [2015] szerint három módszer releváns: a költség-haszon elemzés, az input-output elemzés és a számszerüsített általános egyensúlyi modellek (Computable General Equilibrium Models, CGE).

Dwyer és szerzötársai [2016] a gazdasági hatáselemzés (Economic Impact Analysis, EIA) fogalmát jóval szűkebben definiálja, a melynek fö eszközei az input-output elemzés, valamint az országos és területi multiplikátorok (lásd például az amerikai RIMSII modellt, Ambargis-Mead [2012]). Az input-output módszerrel kifejezett gazdasági hatások nem azonosak a költség-haszon elemzés középpontjában álló nettó haszonnal, a két módszer eltérő eredményre vezet. Nem egyszerủen összegszerủ differenciáról, hanem tartalmi különbségröl van szó.

Ahogy az input-output elemzésnél fontos a területi lehatárolás, úgy a költséghaszon elemzésnél is meg kell határoznunk, hogy a vizsgált jelenség hatására a gazdasági szereplők mely csoportjának jólétében bekövetkező változásokat akarjuk kifejezni. Az egyéni és a teljes társadalom szintje közötti átmenetekhez tartozó határokat nehéz egyértelmủen definiálni. Emiatt sokszor esetleges, hogy az egyes elemzők milyen tényezőket és milyen módon vesznek figyelembe a költségek és a hasznok között.

Egy fesztivál teljes körü költség-haszon elemzése során mindenféle könnyen és nehezen monetarizálható társadalmi és pénzügyi költséget és hasznot számításba kellene vennünk, amit egy fesztivál eredményez. Kétségtelen, hogy ez lenne a legalkalmasabb arra, hogy a hatásokat komplex módon kezeljük. A költség-haszon elemzés módszerével végzett korábbi kutatásaink (Solt-Takács [2015], Koppány [2016]) tapasztalatai alapján azonban tudjuk, hogy az információk hiánya, a társadalmi és jóléti költségek és hasznok

\footnotetext{
${ }^{6}$ Itt érdemes megjegyezni, hogy a fesztiválok a rendezvényturizmus egyik elemét jelentik, a kutatási terület abból vált ki.
} 
értékelésének nehézségei miatt ez a modell túlságosan összetett munkát igényel ahhoz, hogy egy fesztivál gazdasági hatását ilyen módon határozzuk meg. Egy megalapozott költség-haszon elemzéshez még egyetlen fesztivál esetében is jelentős erőforrásokra, az általunk alkalmazottnál jóval mélyebb és hosszabb kérdőívekre, a megkérdezettek idejét sokkal jobban igénybe vevő felmérésekre és komoly kérdezőbiztosi szakértelemre volna szükség. Projektünk keretei nem tették volna lehetővé, hogy egy ilyen eljárást több fesztiválon kipróbáljunk. Nem véletlen, hogy a költség-haszon elemzés alkalmazása meglehetősen ritka a hatástanulmányok során.

Az input-output táblákon és társadalmi elszámolási mátrixokon alapuló gazdasági hatáselemzés a költség-haszon elemzéshez képest egy zárt, konzisztens rendszeren alapuló technika, amely azonban a különféle ár-, helyettesítési és kiszorítási hatások figyelmen kívül hagyásával eltúlzott becslésekhez is vezethet. Dwyer és szerzőtársai [2016] éppen az ilyen effektusok megragadására is képes CGE modellekben látja a gazdasági hatáselemzés és a költség-haszon elemzés összeegyeztetésének egyik lehetőségét, a költség-haszon elemzés szigorúbb, elméleti szempontból is kielégítő keretek közé terelését (erről lásd még KoopmansOosterhaven [2011] tanulmányát).

A számszerüsített általános egyensúlyi modellek ugyan jól használhatók a kiszorítási hatások és a strukturális változások modellezésére, rövid távú és regionális összefüggésekre, egyéni gazdasági szereplőkre való alkalmazásuk, adatokkal való feltöltésük, paraméterezésük, kalibrálásuk azonban komoly módszertani és adaptálási kihívásokkal jár. A meglehetősen kevés nemzetközi és saját tapasztalat alapján nem láttuk megalapozottnak a fesztiválokra való alkalmazásuk sikerét. Nem mondtunk le azonban arról, hogy a jövőben kidolgozzunk és kipróbáljunk egy ilyen modellen alapuló megoldást is, illetve Dwyer és szerzőtársai [2016]-hoz hasonlóan keressük az input-output elemzés és a költség-haszon elemzés összeegyeztetésének, együttes alkalmazásának lehetőségét.

Kutatócsoportunk tagjainak korábbi eredményei, kutatási tapasztalatai (Koppány [2017a]), a fesztiválokról elérhető, valamint a fesztiválszervezőktől és a -látogatóktól összegyüjthető adatok alapján a projekt időbeli, anyagi és egyéb keretei között reálisan felmutatható eredményeket kizárólag az input-output módszertől várhattunk. Ennek segítségével a gazdasági szereplők és ágazatok értékláncain tovagyűrűző hatások számszerüsítésével kifejezhető a fesztiválok országos és regionális makroteljesítményhez való hozzájárulásának mértéke.

A hazai szakirodalomban meglehetősen kevés kutatás foglalkozik a fesztiválok hatáselemzésével. Idetartoznak például a KPMG vizsgálatai a nagy zenei fesztiválokról vagy Kundi Viktória elemzései, azonban ezek egyike sem törekedett teljességre. A KPMG teljes kutatási anyaga nem hozzáférhető, de a kapcsolódó rövid publikációból kiderül, hogy az alkalmazott input-output módszerrel „csak a végfelhasználói költések (azaz a rendezvénnyel kapcsolatos fogyasztás) gazdaságban tovagyürüző hatásait” számszerüsítették (Indra [2009] 31. o.). Kundi [2013] pedig kizárólag a szervezők gazdasági adatait használta fel. 


\section{$\mathrm{Az}$ alkalmazott elemzési keret}

Modellünk az előzőknél jóval komplexebb megközelítést alkalmaz, amelynek keretében felmérjük és megbecsüljük a látogatók fogyasztását, meghatározzuk a szervezők ráfordításait és közvetlen teljesítményüket, kalkuláljuk a szervezői beszállítók és az egyéb szolgáltatók teljesítményét, s ezek alapján modellszámításokat készítünk többek között a rendezvény által generált összes hozzáadott értékre, foglalkoztatásra és az egyes adóbevételek nagyságára. A hozzáadottérték- és foglalkoztatási hatásokat nemcsak összességében, hanem ágazati összetételében is számszerüsítjük, így a nemzetgazdaságra gyakorolt tovagyürüző hatásokat differenciáltan, a kapcsolódó szektorok multiplikatív jellemzőinek figyelembevételével tudjuk meghatározni.

A végső kereslet szintjében, ágazati és területi szerkezetében, valamint a gazdaság ágazati kapcsolataiban bekövetkező strukturális változások hatásainak elemzésére Magyarországon (értsd: a magyar gazdaságra vonatkozóan) nem áll rendelkezésre olyan kereskedelmi forgalomban hozzáférhető modell és hozzá kapcsolódó szoftver, mint például az Egyesült Államokban a RIMSII (Ambargis-Mead [2012]) vagy az IMPLAN, vagy az Egyesült Királyságban a Cambridge Econometrics LEFM vagy EEFM modelljei. A fesztiválok gazdasági hatáselemzése tipikusan olyan terület, ahol az ilyen vagy ezekhez hasonló modellek és szoftverek jól alkalmazhatók lennének.

A kutatás során éppen ezért egy hasonló elveken nyugvó hatáselemző modell prototípusának kifejlesztésére vállalkoztunk, amely egyrészt a hivatalos hazai ágazati statisztikai adatokkal, másrészt a fesztiválszervezők és a -látogatók kérdőíves felméréseiből származó információkkal dolgozik. A modell döntően az input-output elemzés módszereire épül, ezek részletes ismertetése megtalálható többek között Zalai [2012] vagy Koppány [2017a] könyvében.

\section{Fesztiválok által generált bevételek és kiadások}

A fesztiválok gazdasági hatáselemzéséhez használt modell kiindulópontjait, legfőbb bemeneti adatait az 1. ábra foglalja össze. A modell keresletoldali megközelítést alkalmaz, így a fesztivál által generált végső keresletből, a fesztivállátogatók belépőjegyeket is magában foglaló összes kiadásából indulunk ki (a jobb felső sarokban látható téglalap). Ezek közül a jegyek, bérletek ellenértéke a fesztiválszervezőkhöz áramlik, s a támogatásokkal és a reklámokból, jogdíjakból származó üzleti bevételekkel együtt megjelenik a fesztiválköltségvetés bevételi oldalán. (A jegybevételekhez hasonló tételek lehetnek még más, közvetlenül a szervezők által értékesített szolgáltatások vagy ajándéktárgyak eladásából befolyó összegek, ezek jelentősége azonban rendszerint csekély.)

A látogatók költéseinek másik, jellemzően a jegyekre, bérletekre költött összegeknél jóval nagyobb része meg sem jelenik a szervezők költségvetésében. Ilyenek az utazásra, szállásra, ételek és italok fogyasztására, ajándéktárgyak vásárlására és egyéb programokra fordított kiadások az 1. ábra jobb oldalán. Ezeket a látogatók közvetlenül a fesztiválok externális hatásait élvező gazdasági szereplőknél költik el. 
1. ábra

Fesztiválok bevételei és kiadásai, fesztivállátogatók költései

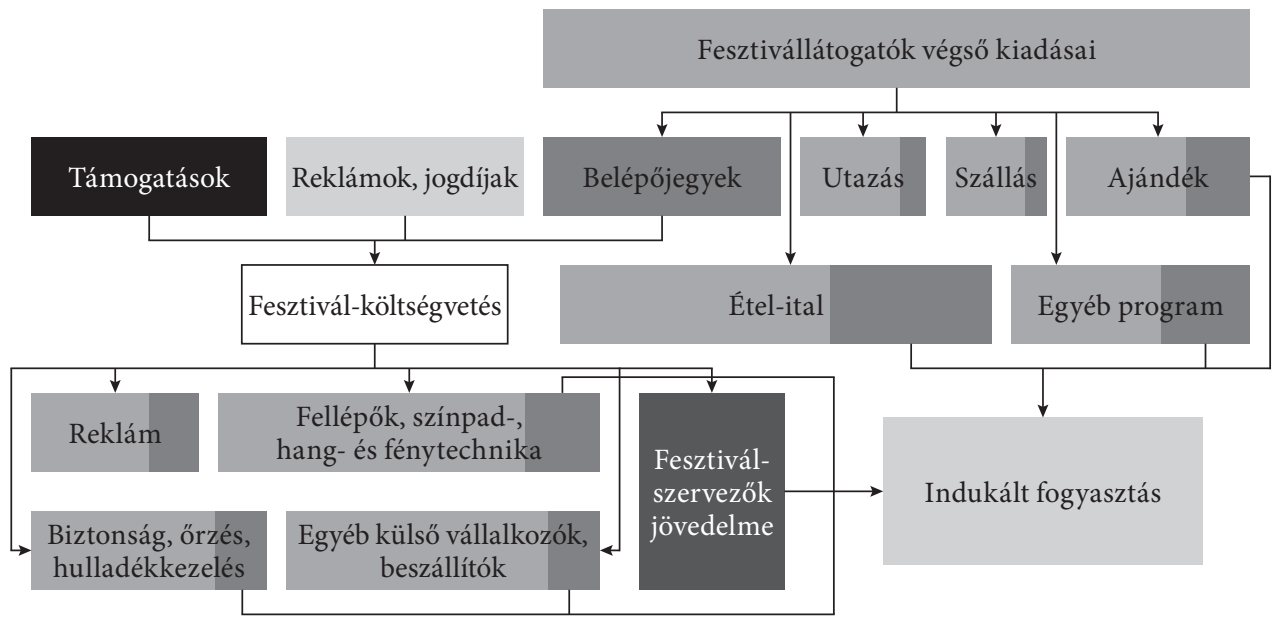

Forrás: Solt és szerzőtársai [2019] alapján saját szerkesztés.

A fesztiválszervezői bevételek nagyobb része a közreműködő beszállítóktól igénybe vett szolgáltatások költségeit, a kapcsolódó anyagjellegü ráfordításokat, vagyis a rendezvény folyó termelőfelhasználását finanszírozza a fesztiválköltségvetés kiadási oldalán: a fellépő előadók honoráriumát, a színpad-, hang- és fénytechnika, az őrzési tevékenység, a biztonsági szolgálat, a takarítás és zöldterület-kezelés, a fesztivál reklámozásának, hirdetésének stb. költségeit. A kiadási oldal másik része a fesztiválszervező cég és munkavállalóinak tőke- és munkajövedelme, vagyis a fesztivál hozzáadott értéke lesz. A piaci alapon szerzett bevételek és a termelöfogyasztás különbségeként adódó hozzáadott érték a fesztiválszervezők többségénél negatív, hiszen különféle támogatások nélkül a piaci bevételeik nem érnék el a termelöfelhasználás értékét. Ez annak ellenére igaz, hogy a hozzáadott értéknek pozitív előjelü komponensei is vannak. Ilyenek például a fesztiválszervező alkalmazottainak kifizetett munkajövedelmek és járulékaik.

Természetesen a beszállítók számára tett megrendelések értékében, valamint a közlekedési szolgáltatók, a szállás- és vendéglátóhelyek, árusok bevételeiben is kimutathatók ezek a (jóval nagyobb valószínűséggel pozitív) hozzáadottérték-tartalmak, amelyeket a kapcsolódó téglalapok jobb oldalának besötétített részei illusztrálnak. A fesztiválszervezőkkel ellentétben ezek nagyságáról a beszállítókat és a többi szolgáltatót már nem kérdeztük meg, hanem az ágazatra jellemző hányadokkal, illetve multiplikátorokkal számoltunk tovább.

Az 1. ábra sugallja ezeknek a jövedelmeknek az elköltéséböl - az úgynevezett indukált fogyasztásból - származó tovagyürüző hatásokat is. Ezek valójában már nem is az elsődleges, hanem az ún. 2. típusú multiplikációs körfolyamathoz tartoznak. Az 1. típusú multiplikatív hatások figyelembevétele során a fesztiválok hatására keletkező jövedelmeknek az elköltését még nem vesszük figyelembe, hanem csupán azt, hogy a fesztivállal kapcsolatos kiadások következtében nemcsak a közvetlenül érintett gazdasági szereplőknél (első körös fesztiválbeszállítók, fellépők, egyéb szolgáltatók), 
hanem ezek beszállítóinál, majd az ő beszállítóiknál, vagyis a teljes vertikális értéklánc felső - úgynevezett upstream - szakaszának minden szereplöjénél keletkezik valamekkora tiszta jövedelem termelőfelhasználásaik levonása után.

\section{Fesztiválszervezői adatfelvétel}

A szervezők bevételeit, kiadásait, az általuk foglalkoztatottak számát, az értékesítési helyet bérlő vendéglátósok és árusok számát, megyei megoszlását és a látogatók általuk becsült számát számítógépes ürlapokkal a vezetőkkel és a gazdasági ügyekért felelös munkatársakkal folytatott mélyinterjúk, szakmai konzultációk során mértük fel. Ehhez egy speciális adatközlő munkafüzetet dolgoztunk ki, ahol a legfontosabb, legjellemzőbb bevételeiket és ráfordításaikat, vagyis a fesztiválköltségvetés szerkezetét kérdeztük meg. Annak érdekében, hogy az ágazati multiplikátorokon alapuló elemzést el tudjuk végezni, az anyagjellegü ráfordításokat ágazati bontásban kértük megadni. A regionális hatáselemzéshez az adott megyén (ahol a fesztivál megrendezésre került) belülről érkező szervezői bevételeket és a megyén kívülre áramló szervezői kiadásokat, a megyén kívüli beszállítókkal szembeni ráfordításokat százalékos arányok segítségével igyekeztünk elválasztani a megyén belüli bevételektől és ráfordításoktól.

A fesztivál munkafelhasználását éves egyenértékes létszámmal (full-time equivalent, FTE) becsültük. A fesztiválok jellemzően három-négy napos rendezvények. A fesztiválszervezőnek lehetnek olyan teljes vagy részmunkaidős (hat- vagy négyórás) alkalmazottai, akik egész évben ennek az évente egyszer megrendezett eseménynek a szervezésével foglalkoznak, s lehetnek olyanok is, akik csak a fesztivált megelőző vagy éppen az ezt követő egy-két hónapban látják el a kapcsolódó feladatokat. Utóbbiak esetében kéthavi munkavégzéssel, az alkalmi foglalkoztatottak (egyszerüsített foglalkoztatott, efo) esetében pedig a megadott összes efo-munkanappal számolva, arányosítva határoztuk meg az éves egyenértékes létszámot.

A regionális elemzést előkészítendő kérdeztünk rá a vásározók (vendéglátósok, árusok) területi összetételére is. A darabszámok alapján számított arányok természetesen nem feltétlenül mutatják pontosan az értékben mért változók (kiadások, bevételek és jövedelmek) területek közötti áramlását, az ezekre való közvetlen rákérdezés a fesztiválszervezői kérdőívben azonban üzleti titkot sértett volna. Harmadik félre vonatkozó adatot (még ha ennek birtokában is voltak) a fesztiválszervezök nem adhattak ki, ezért ilyet nem is kértünk. Áthidaló megoldásként az előbbiekben leírt módon közelítettük meg a problémát. ${ }^{7}$

A látogatók számára vonatkozó kérdés is bekerült a szervezői adatközlő munkafüzetbe, amelyre a jeggyel és bérlettel látogatható vagy valamilyen regisztrációhoz kötött fesztiválok esetén a szervezők pontos válaszokat tudtak adni. Ingyenes

\footnotetext{
7 A vásározók egyenkénti lekérdezése feltehetően jóval pontosabb képet adott volna, ez azonban a jelenlegi erőforrásainkkal nem volt végrehajtható, és valószínűleg eredménye sem lett volna, hiszen a vásározók üzleti okok miatt nem valószínű, hogy megadták volna bevételeik és kiadásaik nagyságát. A tisztán üzleti vállalkozáson alapuló fesztiválok szervezői esetében is általában hasonló magatartást tapasztaltunk.
} 
fesztiválok esetén a szervezői létszámbecsléseket használtuk fel a látogatónapok számának kalkulációjához.

Az éves számviteli beszámolók adataiból ezek az információk nem vagy csak nagyon korlátozottan lettek volna kinyerhetők. A fesztiválszervezés lényegében egy projektfeladat, amelynek tartama nem minden esetben esik egybe a teljes gazdasági évvel. A legtöbb szervező esetén ráadásul a vizsgált fesztivál lebonyolítása mellett a cégnek más tevékenységei is vannak, egyszerre több projektet (akár több fesztivált) is bonyolít, de nem mindig végez projektcentrikus nyilvántartást. Ezért sok esetben még maguk a szervezők sem tudják pontosan meghatározni, mekkora és milyen ráfordításokkal, illetve bevétellel járt az adott rendezvény. Az ilyen esetekben végrehajtott szakértői becslések ellenére elmondhatjuk, hogy a fesztiválok megszervezéséhez kapcsolódó kiadásokat és bevételeket, jövedelmi és foglalkoztatási adatokat lényegében teljeskörüen sikerült megismernünk, s a fesztiválok nemzetgazdasági hatásainak a szervezőkön keresztül áramló bevételekből és kiadásokból kiinduló része még így is viszonylag pontos és megbízható információkra épül. Amint azt a későbbiekben látni fogjuk, ezek a tételek azonban a gazdasági hatásoknak csak a kisebb részét hordozzák. A látogatói költések szerepe ennél jóval nagyobb.

\section{Fesztivállátogatói adatfelvétel}

A látogatók fogyasztása a szervezői adatoknál jóval kevésbé dokumentált. Egyetlen kivételt a belépőkre fordított kiadások jelentik, amelyeket jól lehet mérni. De ezt a szervezőktől felvett bevételi adatok, $s$ talán még a számviteli beszámolók is pontosan megmutatják. Éppen ezért a belépőjegyek árát a látogatóktól is megkérdezni felesleges. Minden más fogyasztás azonban csak primer, látogatói adatfelvétellel határozható meg.

A fesztiválközönség költését helyszíni, személyes megkérdezésen alapuló kérdőíves felmérésekkel vizsgáltuk. Összesen 15365 rövid, a látogatók demográfiai adataira vonatkozó, valamint 5541 részletes, költésük termék- és szolgáltatáscsoportok szerinti szerkezetére is kitérő kérdőívet sikerült felvennünk a rendezvények látogatói körében. A látogatókat a fesztivál idején - különböző napszakokban és helyszíneken a programokhoz igazítva arányosan - a véletlen mintavétel szabályainak betartására törekedve kérdeztük. A demográfiai mintába igyekeztünk minél több látogatót bevonni, ugyancsak a véletlen mintavétel szabályai szerint. Itt csak a nemre, korra, iskolai végzettségre, lakóhelyének megyéjére kérdeztünk rá, illetve arra, hogy milyen távolról (hány kilométerről) érkezett a fesztiválra. Ezekre az egyszerű kérdésekre sokkal többen hajlandók válaszolni, mint egy hosszabb kérdöívre. A fogyasztási adatok részletes felmérését (a rövid kérdöív kérdései ebben is szerepeltek) szükség esetén a demográfiai minta segítségével korrigáltuk. A rövid kérdőív demográfiai adatait mindig összehasonlítottuk a hosszabb kérdőívre válaszolók demográfiai adataival, és nagyobb eltérés esetén súlyozással igazítottuk ki a fogyasztási adatokat. Az így kapott eredmények ugyan még mindig nem feltétlenül teljesítik a szigorú valószínüségi mintavétel (Babbie [2017]) követelményeit, de legalább nem teljesen önkényesen kiválasztottak. 
A látogatói mintavétel és a fogyasztás mérése több okból is nehézségekbe ütközött. a) Az ingyenes fesztiválok sokszor területileg nem lehatároltak, nincsenek fix belépési pontok, ahol a belépő személyekből véletlen mintát lehetne venni. b) Előfordul, hogy egy fesztivál egyszerre négy vagy öt településen zajlik, akár 10-15 helyszínen. c) Eltérő a válaszadási hajlandóság: a nők, a képzettebbek és a távolabbról érkezők általában nagyobb arányban hajlandók egy hosszabb kérdőívre válaszolni, mint a férfiak, a képzetlenebb csoportok és a helyiek. d) A látogatóknak nem könnyű felidézniük, mire és mennyit költöttek. A kérdezés időpontja nem lehet a fesztivál vagy az adott nap vége, amikor már biztosan nem fognak többet költeni. Ehhez rengeteg kérdező éjszakai munkájára lenne szükség, ráadásul a záráskor távozók „józan ítélőképessége” még kétségesebb.e) Az előző napi költésre való rákérdezésnek a jelentős elemszám- és információvesztés a legfőbb hibája. Az utolsó nap így kiesik, miközben a legtöbb fesztivál legfeljebb 2,5 napos. A megkérdezett látogatóktól így azt kértük, hogy a már megtörtént, illetve tervezett napi fogyasztásukról számoljanak be, vagy adjanak rá becslést.

Bár a kiadásokra vonatkozó adatok feldolgozása során természetesen a szokásos módon kezeltük a szélső értékeket (a kiugró adatokat figyelmen kívül hagytuk), az eredmények pontatlanságával számolnunk kellett. Mivel ez minden fesztiválra igaz, a fesztiválok összehasonlításánál kiindulhatunk abból, hogy a torzítás mindenütt hasonló mértékű, vagyis a fesztiválok közötti különbség mértéke valós. Becsléseink elfogadhatóságát jelzi, hogy a kiadások szerkezete a különböző fesztiváloknál hasonló, valamint hogy azok a fesztiválok, amelyeken nagyobb kiadásokat regisztráltunk, drágább árukínálattal rendelkeztek, illetve a nagyobb költést a fesztivál jellege és müfaja is indokolta.

Megállapíthatjuk, hogy a fesztivállátogatók költéseiről készült felmérés képet ad a vizsgált területről, információkat szolgáltat a nagyságrendekről és az arányokról, azonban az adatok nem feltétlenül alkalmasak arra, hogy az egyes fesztiválok teljes látogatói körére vonatkozóan statisztikailag megalapozott általánosításokat vonhassunk le belölük. Látogatói felméréseinket ily módon nem tekinthetjük reprezentatívnak, hiszen a teljes sokaságot, annak összetételét nem ismerjük.

Annak érdekében, hogy a látogatói költéseket azok szerkezete alapján az input-output modellben különböző ágazatokhoz tudjuk rendelni, valamint a regionális elemzésnél meg tudjuk különböztetni a különböző területekről és szándékkal érkező vendégek kiadásait, a kérdőívben külön rákérdeztünk az utazásra (üzemanyagra, tömegközlekedésre), szállásra, étel- és italfogyasztásra, ajándékra és egyéb programokra fordított kiadásokra, valamint a látogatók lakóhelyére és látogatásuk céljára is. Az egyes ágazatokhoz áramló bruttó bevételeket így hat látogatói csoportra becsültük meg: 1. helyi vagy a fesztivál miatt érkezett megyei lakos, 2 . nem a fesztivál miatt érkezett megyei lakos, 3. a fesztivál miatt más megyéből érkezett belföldi, 4. más megyéből, de nem a fesztivál miatt érkezett belföldi, 5. a fesztivál miatt érkezett külföldi, valamint 6. nem a fesztivál miatt érkezett külföldi.

A bevételek túlnyomó része a TEÁOR 55-56: Szálláshely-szolgáltatás, vendéglátás ágazatnál jelentkezik. A kérdőívekben a szállásra és vendéglátásra fordított kiadásokat ugyan megkülönböztettük egymástól, a KSH által publikált 65 ágazatos inputoutput tábla azonban a fentiek szerint összevontan kezeli ezeket. Kétjegyú TEÁOR 
kódok szerinti, 88 ágazatos bontású táblázatot a hivatal nem tudott a rendelkezésünkre bocsátani. Így a fesztiválok hatásaiban leginkább érintett két ágazat tovagyürűző hatásait sajnos nem tudtuk differenciáltan kezelni. Az ajándékokra és az egyéb programokra fordított kiadások ágazati bontását (élelmiszeripar, textilipar, faipar, papíripar stb., illetve művészeti, kulturális vagy sport, szórakoztató tevékenység) a fesztivál jellege és árukínálatának összetétele alapján becsültük.

A teljes költést az egy látogatónapra jutó kiadások és a látogatónapok számának szorzataként határoztuk meg. A teljes sokaságra vonatkozó látogatónapok száma ingyenes fesztiválok esetén kizárólag a szervezői becsléseken alapult. Az ugyanazon fesztiválra több forrásból kapott becslések szórása alapján ez az adat meglehetősen bizonytalan. A bizonytalanság csökkentésében a látogatószámlálás fejlett informatikai módszerekkel, drónos, arcfelismerő és mozgáskövető hardver- és szoftvereszközökkel történő támogatása segíthet, amelynek kutatása ugyancsak a projekt része volt (U1 Nonprofit [2019]).

\section{Input-output táblák, input-output multiplikátorok}

Az input-output elemzés alapvető adatbázisa az ágazati kapcsolatok mérlege (ÁKM) vagy más néven az input-output tábla. A kettős „könyvelés” szabályain alapuló táblázat a gazdaság termelöágazatainak és felhasználó szektorainak kapcsolatrendszerét mutatja egy adott évben, soronként kibocsátási (output), oszloponként felhasználási (input) oldalról. Ez a részletes kimutatás (az 1. táblázatban az illusztráció kedvéért csupán egy hat ágazatra összevont ÁKM szerepel) a nemzeti számlák adataival konzisztens, ugyanaz a makrogazdasági teljesítmény (kibocsátás, GDP) olvasható ki ebből is. Ebben a teljesítményben megjelenik - s ily módon a táblázat adataiban is ott van - a fesztiválok hatása, hozzájárulása, amelyet megpróbálunk elkülöníteni. Gyakorlatilag ez kutatásunk fö kérdése: hogyan, milyen mutatók esetében és milyen mértékben jelentkeznek ezek a hozzájárulások? Mekkora hatást gyakorol egy adott fesztivál a makrogazdasági kibocsátásra, a hozzáadott értékre (GDP-re), a foglalkoztatásra és a munkajövedelmekre? A kérdések megválaszolásához először is a fesztiválokhoz kapcsolódó áramlásokat, az előzőkben leírt módon lekérdezett és meghatározott bevételeket és kiadásokat kell megfelelően elhelyeznünk, pontosabban elkülönítenünk a nemzetgazdasági input-output táblában (1. táblázat).

Gondolkodjunk most egyetlen fesztiválban! ${ }^{8}$ A szervező tevékenysége alapján leginkább a TEÁOR 90-92: Alkotó-, müvészeti és szórakoztató tevékenység vagy a 93: Sport-, szórakoztató, szabadidős szolgáltatás ágazatba sorolható (utóbbi az általunk vizsgált fesztiválok esetén nem volt jellemzö), így kibocsátása, értékesítései benne vannak az összevont 1. táblázat J-T Egyéb szolgáltatások sorának számaiban. A fesztiválszervezőtől kapott bevételi adatok alapján a fesztivált kiemelhetjük az ágazat többi szereplöje közül,

\footnotetext{
${ }^{8}$ Az egyéni gazdasági szereplőkre, egyedi vállalatokra vonatkozó input-output elemzésnek, a gazdaság rendszerében történő integrált kezelésüknek is széles, nagy múltra visszatekintő irodalma van (lást például Tiebout [1967], Billings-Katz [1982], Polenske [1997]). Találunk példákat egyetem (Lenzen és szerzőtársai [2010], Armstrong [1993]), reptér (Batey és szerzőtársai [1993]), papíripari (Greig [1971]) és jármüipari vállalat (Koppány-Steszli [2017]) hatáselemzésére is.
} 


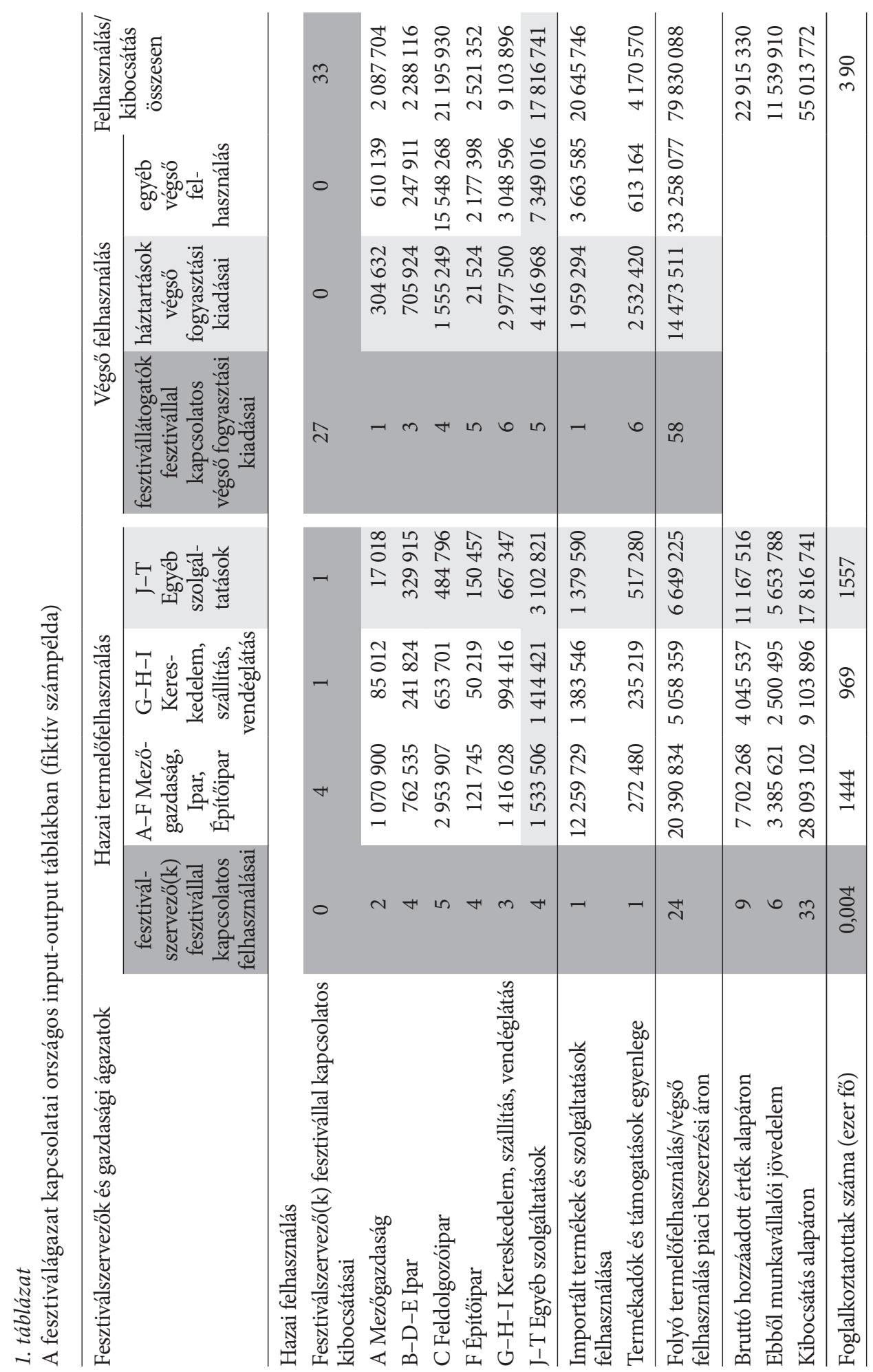

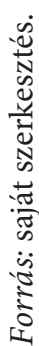


s értékesítései számára egy külön sort (az 1. táblázatban sötét háttérrel) nyithatunk. A fesztivál kibocsátásai egyrészt más ágazatok felé (például reklámfelületek értékesítése, elárusítóhelyek bérbe adása stb.), másrészt a látogatók felé áramlanak (ezek elsősorban a belépőjegyek értékesítéséből származó bevételek, másodsorban idetartozik minden egyéb, közvetlenül a látogatóktól származó szervezői bevétel).

Hasonló módon szeparálhatjuk a vizsgált fesztivált felhasználási oldalról is költségvetésének kiadási tételei alapján, amelyek a kapcsolódó szolgáltató ágazat termelöfelhasználás oszlopának részei. Innen kell kiemelnünk és egy számára nyitott külön oszlopba (sötét háttérrel) áthelyeznünk a szervezö által más ágazatokból vásárolt termékek, szolgáltatások (anyagjellegü fordítások) értékét, a rendező szervezet hozzáadott értékét (ennek részeként a kifizetett munkajövedelmeket), kibocsátását és az általa foglalkoztatott létszámot.

A fesztivál sora ily módon a gazdaság más szereplőivel való értékesítési relációit, oszlopa pedig a más hazai ágazatoktól (illetve importból, ha van, ez az általunk vizsgált fesztiváloknál nem volt jellemző) származó beszerzéseit (termelőfelhasználását), valamint közvetlen hozzáadott értékét mutatja.

A fesztivállátogatók fesztivállal kapcsolatos végső fogyasztási kiadásai (utazás, szállás, belépőjegy[ek], étel- és italfogyasztás, ajándéktárgy-vásárlás a fesztivál helyszínén, a kapcsolódó egyéb kulturális, sport- és szabadidős szolgáltatások igénybevételéért kifizetett összegek stb.) ugyanígy megtalálhatók az ÁKM-ben, ezeket a háztartások fogyasztási kiadásai oszlopból kell áthelyeznünk a fesztivállátogatók fesztivállal kapcsolatos végső kiadásainak oszlopába (sötét háttérrel). ${ }^{9}$

Az előzőkben bemutatott szeparációs technika is jól mutatja, hogy a kutatás során szándékosan igyekeztük kerülni a fesztivállal kapcsolatos kiadások pótlólagos keresletként történő beállítását, noha annak egy része biztosan ilyen értelemben is számításba vehető, míg más része minden bizonnyal meglévő keresletet szorít ki (az adott összeget nem a fesztiválra költötték volna, hanem valami másra). Hasonlóképpen a hatásokat sem növekményi szemléletben értelmezzük. Az eredményekre tehát nem úgy tekintünk, hogy a fesztivál következtében ennyivel lett több a kibocsátás, magasabb a GDP vagy a foglalkoztatás, hanem sokkal inkább úgy, hogy a KSH által közölt adott időszaki (évi) kibocsátásból, a GDP-ből vagy a foglalkoztatásból becsléseink és modellszámításaink alapján ennyi és ennyi köthető az adott fesztiválhoz mint a ténylegesen megvalósult végső kiadások tényleges végső okához (vagyis ex post szemléletü elemzést végzünk). A különféle helyettesítési és kiszorítási hatásokkal tehát ilyen értelemben nem foglalkozunk.

Ezek a kérdések a kutatócsoport tagjai és a bevont fesztiválszakmai szakértők között is sokszor előkerültek, és értékes, a közös gondolkodást elörevivő szakmai vitákat eredményeztek. Az input-output elemzés alkalmazási lehetőségeit korlátozó, a szakirodalom által gyakran emlegetett tényezőknél (kiszorítási, helyettesítési és egyéb hatások, lásd

\footnotetext{
${ }^{9}$ A fesztiválokhoz kapcsolódóan számos, gazdaságstatisztikailag a végső felhasználásba tartozó kiadás merülhet fel. Ezek nemcsak folyó kiadások, hanem beruházási jellegűek is lehetnek. Utóbbiakra vonatkozóan nem kaptunk információkat, de kutatásunknak nem is ez volt a fó célja. A fesztivál folyó kiadásainak, adott évi megrendezésének hatásaira koncentráltunk.
} 
például Porter-Chin [2012], Diedering-Kwiatkowski [2015], Crompton-McKay [1994]) sokkal fontosabbnak ítéltük meg a fesztiválokon vagy a fesztiválok idején, azokhoz kapcsolódóan értékesített termékek és szolgáltatások árainak pozitív irányú eltérését a normál árszinthez képest. Ha ezt figyelmen kívül hagyjuk, akkor a normál (átlagos) ágazati árszinttel számított multiplikátorok használata a tovagyűrűző hatások alulbecslését eredményezheti. A beszállítóknak adott megrendelések a bevételek jóval kisebb arányát teszik ki ilyen esetben, s sokkal nagyobb lesz a közvetlen első körös hozzáadott érték. Elméleti síkon is belátható, hogy alacsony importhányadok és regionális elszivárgás esetén a torzítás mértéke elhanyagolható. Viszont minél nagyobb a beszállítói lánc importhányada, annál nagyobb mértékű lehet az eltérés. Ilyen indíttatásból került be a „Hány százalékkal magasabbak az árak a normál árszinthez képest a fesztivál idején/fesztiválon?” kérdés a szervezők táblázatába. Erre a kérdésre azonban a fesztiválszervezők egyike sem válaszolt. Szakértőink ezzel kapcsolatban arra hívták fel a figyelmet, hogy mind a fesztiválok, mind az azokon értékesítő árusok, vendéglátósok bevételei erősen ingadoznak, számos kockázati tényezőnek vannak kitéve. Hogy csak a legkézenfekvőbbet említsük, ha a rossz időjárás miatt alacsony a fesztivál látogatottsága, akkor bevételeik és hozzáadottértékhányaduk is jóval kisebb lesz. A magasabb árszint ezt a magasabb müködési kockázatot hivatott fedezni, s rendszerint több év átlagában biztosítja a szokásos ágazati profitrátát. Így nemhogy nem követünk el nagy hibát, hanem talán úgy járunk el a leghelyesebben, ha a normál ágazati árszinthez tartozó multiplikátorokkal számolunk.

A hatások elemzése természetesen nem áll meg a szeparáció eredményeként adódó, a fesztivál sorában és oszlopaiban megjelenő puszta számoknál. Az input-output modell segítségével nemcsak a közvetlen, hanem a más gazdasági szerepelökre (ágazatokra) tovagyürüző közvetett, sőt a keletkezö többletjövedelmek elköltése által generált (úgynevezett indukált) hatások is számszerüsíthetők. Ezekre később térünk ki.

Ha a hatások területi megoszlására is kíváncsiak vagyunk, akkor regionális inputoutput táblákkal kell dolgoznunk. Magyarországon jelenleg a megye az a legkisebb területi egység, amelyre vonatkozóan (korlátozottan) rendelkezésre állnak azok a statisztikai adatok (például területi hozzáadott érték, területi munkajövedelmek), amelyek alapján az országos input-output táblák regionalizálhatók.

A területi elemzésekhez kétrégiós interregionális input-output táblákat használtunk, amelyek megkülönböztetik a vizsgált régió (a megye, ahol a fesztivál megrendezésre került) és az ország más területeinek (Magyarország összes többi megyéjének) összevont felhasználását és értékesítését. ${ }^{10}$ Ilyenre mutat sematikus példát a 2. táblázat, ahol a fesztiválszervezőt a rendezvénynek otthont adó megye gazdasági szereplőjének tekintettük, a fesztivállátogatók megyei és megyén kívüli gazdasági

${ }^{10}$ A többrégiós (inter- és multiregionális) input-output modellekről lásd Miller-Blair [2012] könyvét vagy magyarul Szabó [2015] tanulmányát. A kétrégiós modell melletti döntésünket a rendelkezésünkre álló adatok indokolták. Sem a fesztiválszervezőktől, sem a fesztivállátogatóktól nem gyűjtöttünk (reálisan nem is várhattunk el) ennél részletesebb adatokat. Csak a fesztivál gazdamegyéjét és az ország más megyéit (összevontan) különböztettük meg egymástól. Sok esetben ez a kettős besorolás is komoly kihívást jelentett mind a válaszadás, mind a feldolgozás szempontjából. Az ezáltal meghatározott kétrégiós keretben viszont törekedtünk a pontosabb (nem csupán technikai, hanem annál precízebb inputkoefficienseken alapuló) interregionális modell alkalmazására. Az interregionális táblázatok becslésének általunk alkalmazott módszereit a Függelékben közöljük. 
szereplőkhöz ${ }^{11}$ áramló kiadásait pedig megyei, megyén kívüli hazai és külföldi ${ }^{12}$ látogatócsoportonként, három külön oszlopban szerepeltettük.

Ezzel a felosztással lehetőség nyílik az elemzési eredmények területi szintű finomítására, illetve a fesztiválok regionális gazdaság szempontjából vett jelentőségét még jobban kifejező turisztikai hatások kimutatására. A nem helybeli lakosság fesztiválköltéseit sokkal bátrabban tekinthetjük pótlólagos regionális keresletnek, amely a fesztivál hiányában a vizsgált régióban (megyében, városban) nem jött volna létre. Ugyanilyen értelemben sokkal valószínűbb az is, hogy a távolról érkező fesztivállátogató nem költötte volna másra ugyanebben a régióban a fesztiválra szánt/elköltött pénzét.

A regionális input-output táblából jól látszik az is, hogy a fesztiválon jelentkező végső és közbülső kiadások, valamint a felhasználások egy része közvetlenül sem feltétlenül az adott megye vállalkozóit, vállalati szektorát gazdagítja. A fesztiválon megjelenő vendéglátóipari szolgáltatók, árusok és a fellépő előadók jelentős része rendszerint nem az adott megyéböl érkezik a fesztiválra. ${ }^{13}$ Lehetnek ugyanakkor olyan interregionális tovagyürüző (spillover) hatások, amelyek az ilyen közvetlenül elszivárgó tételeknél is eredményeznek pozitív visszacsatolásokat. A közvetett és indukált hatások figyelembevételével felbecsülhető tehát az is, hogy az adott fesztivál összességében mekkora értéket képvisel az adott megye és más megyék gazdasági eredményeiben (mekkora hatása van a gazdarégióra és más régiókra).

A fesztivált a szervezőktől és látogatóktól gyüjtött információk alapján az előzőkben bemutatott módon integrálhatjuk az országos, illetve a megyei és országos gazdaság ágazatainak komplex, összefüggő rendszerébe. A fesztivál bevételi és kiadási adatainak külön sorokban és oszlopokban történő kimutatásával lehetőségünk nyílik arra is, hogy más ágazatok, illetve a teljes megyei és országos gazdaság GDPtermelésre és foglalkoztatásra gyakorolt hatásait kiszámítsuk. Ennek egyik lehetséges input-output módszere az úgynevezett hipotetikus eltávolítás, amelynek során arra keressük a választ, hogy milyen hatást gyakorolna a makrogazdasági változóra, ha a fesztivált összes bevételével és kiadásával együtt töröljük a gazdaság rendszeréböl, mintha az meg sem történt volna (lásd Dietzenbacher-Lahr [2013], Koppány [2017b], [2018b], Koppány-Steszli [2017]).

A hipotetikus eltávolítás és más, a teljes input-output táblán alapuló módszerek korrekt alkalmazása megkövetelné, hogy rendelkezzünk a vizsgált fesztiválok évére $(2017,2018)$ vonatkozó országos és regionális ÁKM-mel, amelyben a fesztiválokat az 1. és a 2. táblázatban bemutatott módon szeparálhatjuk. E tanulmány írásakor a KSH által publikált legfrissebb országos ÁKM a 2015-ös évre vonatkozik, amelyet

${ }^{11}$ Vegyük észre, hogy a fesztiválon régión belüli és régión kívüli látogató is költhet úgy, hogy az ebből származó bevétel régión kívüli gazdasági szereplőhöz áramlik közvetlenül, például egy Győr-MosonSopron megyei fesztiválra érkező budapesti látogató lángost vásárol az ott árusító Vas megyei lángossütőtől.

${ }^{12}$ A nem rezidensek közvetlen vásárlásai a hazai piacon is a háztartási fogyasztás részét képezik.

${ }^{13}$ Emlékeztetőül: az ország különböző megyéiből érkező vásározók (vendéglátósok, árusok) számára - a fesztiválszervezők adatközlő munkafüzetében - elhelyezett űrlap segítségével gyűjtöttünk információt. A vendéglátósok és az árusok számának területi eloszlása alapján becsültük meg az étel- és italfogyasztásra, valamint az ajándék vásárlására fordított kiadások területi mozgását, vagyis ezekből a megyén belüli termelőkhöz, szolgáltatókhoz kerülö, valamint a megyéből más megyékbe, esetleg külföldre elszivárgó összegeket. 


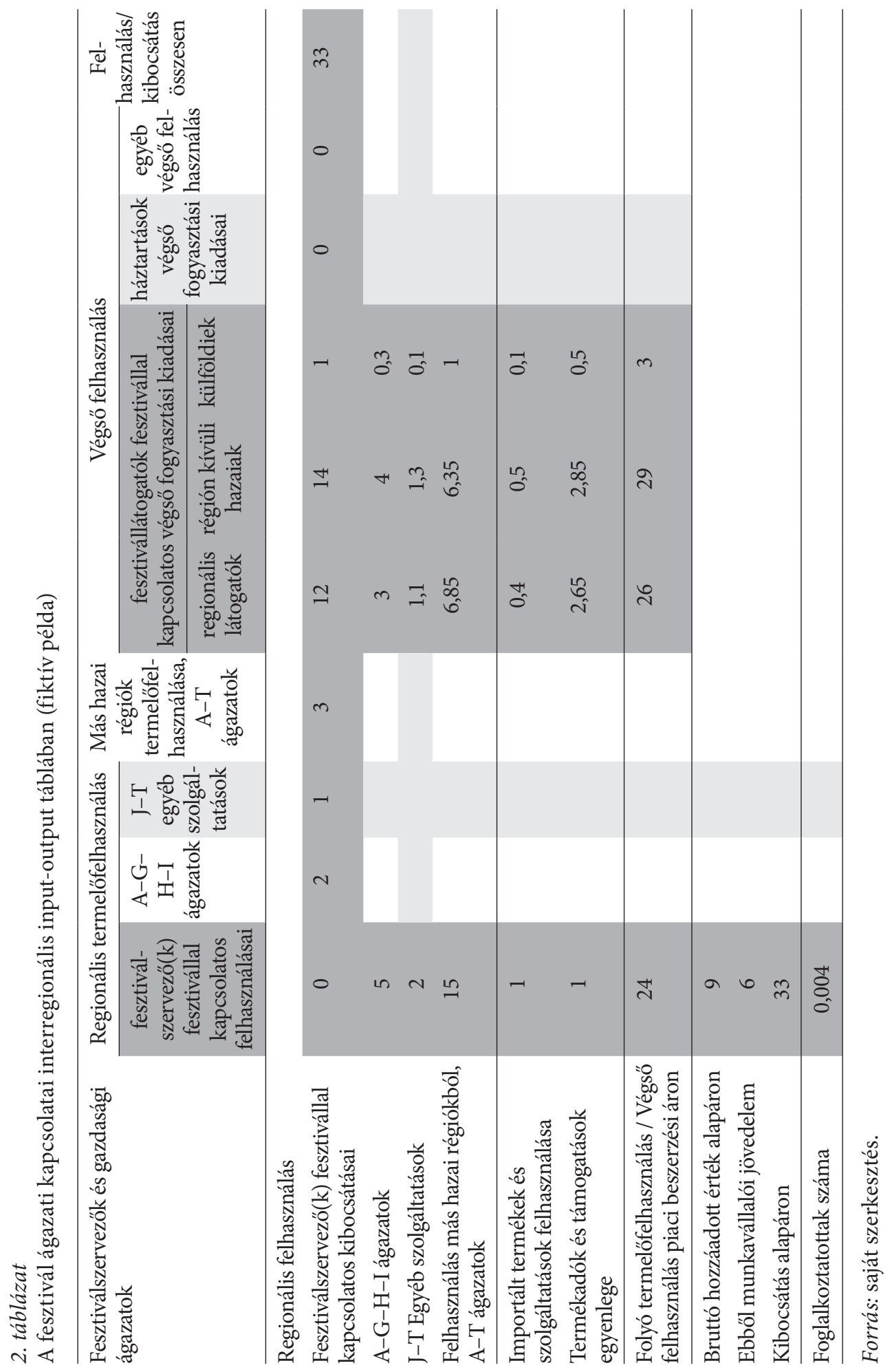


megfelelő módszerekkel (ezekről lásd Koppány [2017a], [2017b], [2018b]) az azóta közzétett peremadatok alapján már tovább tudnánk vezetni akár 2018-ig is, a regionális táblázatok esetén (ilyeneket a KSH nem készít) azonban erre nem lenne lehetőségünk. Kutatásunk kezdetén még csak a 2010. évi ÁKM volt ismert, amelyet a rendelkezésre álló adatok alapján (a fentiekben hivatkozott módszerekkel) ugyan 2015-ig továbbvezettünk, de a hivatalos 2015. évi ÁKM megjelenésekor (2018 végén) átszámoltuk az összes vizsgált fesztivál országos hatáselemzését, $s$ a regionális vizsgálatok során is erre az évre becsült területi táblázatokkal dolgoztunk.

Az input-output táblák és a fesztiválok éveinek eltérése miatt nem teljes táblázatokon alapuló módszerekkel, hanem végső keresleti multiplikátorokkal dolgoztunk, ${ }^{14}$ feltételezve, hogy azok 2015 és 2017-2018 között érdemben nem változtak. A végső keresleti multiplikátorok olyan szorzószámok, amelyek megmutatják, hogy valamely ágazat termékei iránti végső kereslet egységnyi növekedése a közvetlen és a teljes beszállítói értékláncon tovagyürüző hatásokat figyelembe véve mekkora hatást gyakorol a vizsgált makrogazdasági változóra (hozzáadott értékre, foglalkoztatásra stb.). ${ }^{15} \mathrm{Az}$ egyes fesztiválokon jelentkező összes végső kiadásra vonatkozó összetett fesztiválmultiplikátort nem ismerjük, ${ }^{16}$ de a kiadások 2. ábra szerinti elemekre, ágazati komponensekre bontásával viszonylag pontosan megkaphatjuk a hatásokat. Ezzel gyakorlatilag az adott fesztiválhoz köthető összes kiadás egyfajta súlyozott multiplikátora is meghatározható. Tanulmányunk egyik fö eredményeként akár ezt is megjelölhetnénk. A kétféle módon (az összes fesztiválbevételre és a fesztiválköltségvetésre) is kiszámított egyedi fesztiválmultiplikátorok vizsgált rendezvényeken mért értékét a tanulmány végén részletesen elemezzük. Ezekre építjük majd a fesztiválszektor egészének nemzetgazdasági hatásaira vonatkozó becslésünket.

Egyelöre azonban maradjunk az input-output táblákban megtalálható ágazatok multiplikátorainak használatánál! A 2. ábrán látható módon a fesztiválhoz kapcsolódó végső kiadásokat két részre bonthatjuk. Ezek egy része (az ábra bal oldalán) a fesztiválszervezőhöz áramlik, s átfut rajta. Ez gyakorlatilag a jegybevételeket (illetve más, közvetlenül a fesztiválszervezőtől vásárolt termékek, szolgáltatások ellenértékét) jelenti. Ezeket, valamint a szervező bevételei között az 1. ábrán szereplö további tételeket (támogatásokat, reklám- és jogdíjbevételeket) a multiplikátorelemzéshez nem használjuk, ${ }^{17}$ hiszen a tovagyürüző hatásokat nem ezek, hanem

${ }^{14}$ Az országos és megyei multiplikátorok kiszámításának módszereit a Függelékben közöljük.

${ }^{15}$ A tanulmányban közölt eredmények kizárólag ilyen, úgynevezett 1-es típusú multiplikátorokkal való számításokon alapulnak. 2-es típusú, a jövedelmek indukált fogyasztási hatásait is tartalmazó multiplikátorokkal kapott eredmények (amelyek még nagyobb hatásokat mutatnának) ebben az anyagban nem szerepelnek.

${ }^{16}$ A részleteiben kevésbé kidolgozott hatáselemzések ezért egyszerűen a látogatók belépőkön felüli költésével és az annak legnagyobb hányadát kitevő szállás- és vendéglátás ágazat multiplikátorával számolnak.

${ }^{17}$ A fesztiváltámogatások [a Nemzeti Kulturális Alaptól (NKA) kapott, terméktámogatásnak minősülő forrásokat leszámítva] a másodlagos jövedelemelosztás elemeit jelentő transzferek, amelyek nem részei az ágazatok kibocsátásának. Ezért aztán az input-output táblában nem is jelennek meg, csak a részletesebb adattartalmú, az ÁKM kibővítéseként is felfogható társadalmi elszámolási mátrixokban (Social Accounting Matrix, SAM) (lásd Koppány [2017a] 3. fejezet). Multiplikátorelemzés SAM-ekkel is végezhetö (lásd például Révész [2001a]). 


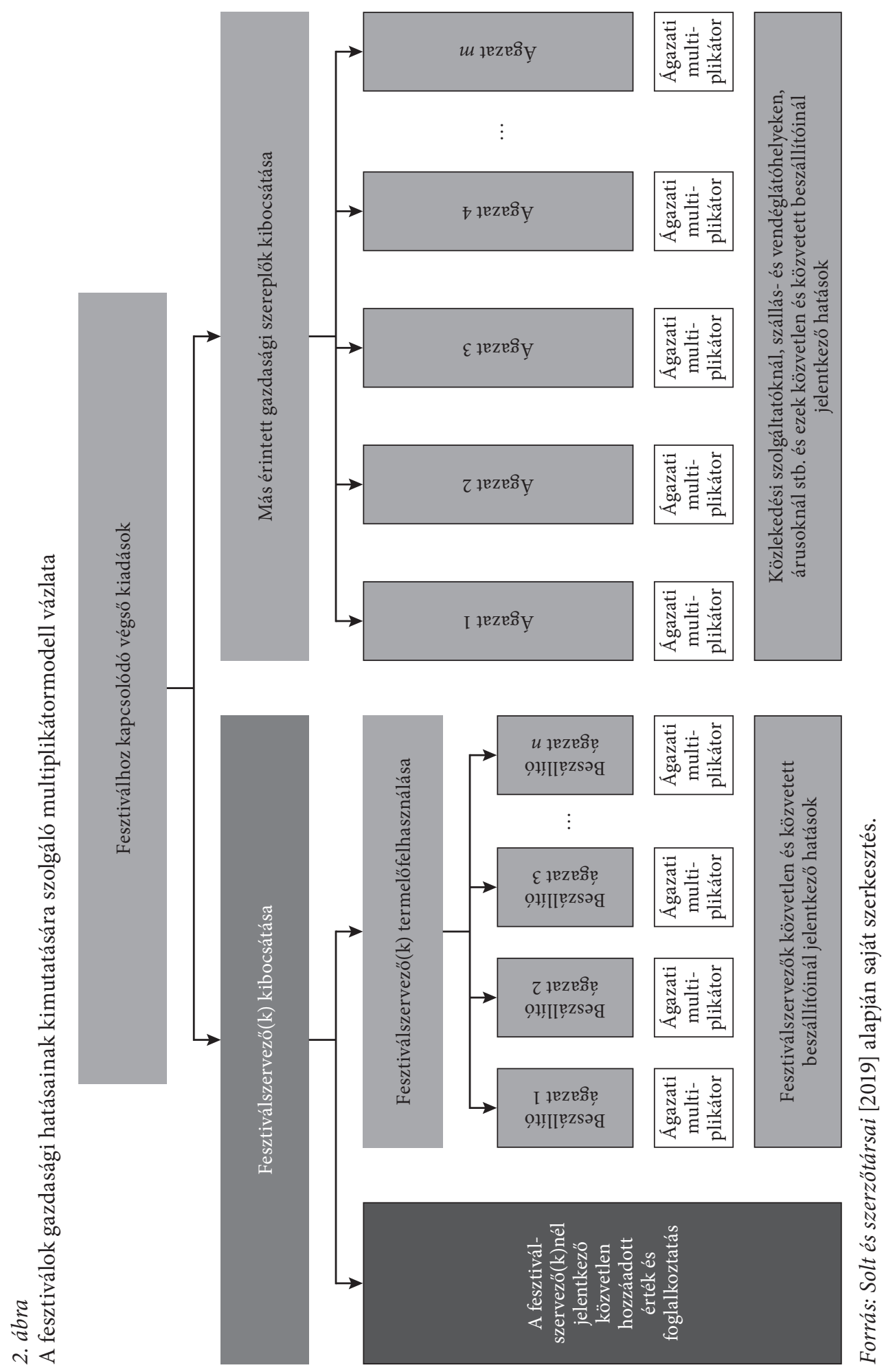


az ezekből megvásárolt szolgáltatások és termékek alapján, a költségvetés kiadási oldalán követjük nyomon. ${ }^{18}$

A szervezőhöz befolyó bevételekhez (a szervező kibocsátásához) kapcsolódó hatások két nagy részre bonthatók. Az egyik a fesztiválszervezőnél a kibocsátása és termelőfelhasználása különbségeként jelentkező közvetlen hozzáadottérték-hatás (illetve az általa alkalmazott létszámban megtestesülö közvetlen foglalkoztatási hatás). A másik csoportba a termelőfelhasználásához (reklám, fellépők, színpad-, hang- és fénytechnika, biztonság, őrzés, hulladékkezelés stb., lásd az 1. ábrán) és a megvásárolt szolgáltatásoknak, termékeknek az eladóihoz, beszállítóihoz köthető hatások tartoznak (nemcsak a közvetlen, első körös, hanem a második, harmadik stb. körös, közvetett szállítókat is beleértve). Ezek számszerüsítéséhez beszállító ágazatonként csoportosítjuk a fesztiválszervező termelőfelhasználását, $s$ a csoportösszegek mindegyikét megszorozzuk az adott ágazat megfelelö (hozzáadottérték- vagy foglalkoztatási) multiplikátorával. Hasonlóan kell eljárni a 2. ábra jobb oldalán látható, más gazdasági szereplőkhöz áramló látogatói költésekkel (szállás, utazás, étel-ital stb.) is.

A hatáselemzés eredményét a 2. ábra alsó részén lévő téglalapoknak megfelelően a következő hármas bontásban kapjuk meg: 1. a fesztiválszervezőnél jelentkező közvetlen hatások, 2. a fesztiválszervező közvetlen és közvetett beszállítóinál jelentkező hatások, valamint 3. az egyéb gazdasági szereplőknél (közlekedési szolgáltatóknál, szállás- és vendéglátóhelyeken, árusoknál stb.) és ezek beszállítóinál jelentkező hatások. A három hatás összege adja a fesztivál teljes hatását.

\section{Piaci árról alapárra való áttérés}

A látogatói és szervezői felmérésekből származó (survey) adatok és az ÁKM-ben szereplő értékek között lényeges különbség, hogy míg az előzők piaci árakon, utóbbiak alapáron vannak kifejezve. A multiplikátorok az alapáras felhasználási adatokkal kompatibilisek. A kérdőíves felmérésekből származó adatokat ezért alapárra kellett konvertálnunk. Ehhez a piaci és alapáras felhasználástáblázatok, árrés- és termékadómátrixok ágazati arányaiból indultunk ki, s ezeket vetítettük rá a kérdőívekből kapott piaci áras termelő- és végső felhasználási adatokra.

\section{A piaci vagy nem piaci termelés kérdése}

A fesztiválok döntő többségénél jellemző negatív közvetlen hozzáadott értékre ezen a ponton térünk vissza. Mint azt korábban említettük, ennek oka, hogy a fesztiválszervezők termelőfelhasználása jóval meghaladja piaci bevételeiket (még ha számviteli értelemben nem is veszteségesek). Azokat a termelőket és szolgáltatókat,

${ }^{18}$ Ehhez a megközelítéshez lásd még Tiebout [1967], Burford-Katz [1977], [1981] és Harrigan [1982] írásait. 
amelyeknél a piaci bevételek nem fedezik kellő mértékben a termelés költségeit, s ez az állapot tartósan fennáll, a gazdaságstatisztika a nem piaci termelők közé sorolja. ${ }^{19}$ Ily módon a szabályok által meghúzott 50 százalékos határvonal alapján az általunk vizsgált fesztiválok között biztosan van olyan, amely a piaci, és olyan is, amely a nem piaci termelők közé tartozik. Ettől függően kellene különbözőképpen számolnunk az egyes fesztiválok kibocsátását és hozzáadott értékét.

A két különböző értékelés azonban egyrészt meglehetősen inkonzisztenssé, nehezen összemérhetővé tenné az egyes fesztiválok gazdasági hatásaira kapott eredményeinket; másrészt az imputolás módszerével történő elszámolás azonnal elrejtené a kellöképpen veszteséges fesztiválok negatív müködési eredményét, így amennyiben egy efféle hatáselemzés szerepet játszik a döntések során, az akár jelentős mértékben is torzíthatná a támogatások hatékony allokációját. Még az a paradox helyzet is elóállhat, hogy minél veszteségesebb egy fesztivál piaci alapon, annál jobbak a nem piaci termelőként számított mutatói, s ezek alapján annál inkább megéri támogatni. Harmadrészt fontos figyelembe venni azt is, hogy kizárólag egy évre vonatkozóan rendelkezünk fesztiválszervezői adatokkal, amelyek alapján a termelők piaci-nem piaci besorolását nem tudjuk megalapozottan elvégezni. A fentiek miatt úgy döntöttünk, hogy - még ha gazdaságstatisztikailag ez nem is minden esetben korrekt - kutatásunk során minden fesztivált piaci termelőként, üzleti alapon értékelünk.

\section{Összehasonlító elemzés és a vizsgált fesztiválok együttes hatásai}

Az előzőkben bemutatott vizsgálati metódust tizennégy fesztiválon terveztük alkalmazni. A látogatói létszám tekintetében mindenesetre nem a legnagyobb fesztiválokra koncentráltunk, elsősorban a közepes méretü fesztiválokat céloztuk meg. Már csak azért is, mert ezek esetében nagyon fontos a fesztivál támogatóinak, az érintett önkormányzatnak a meggyőzése arról, hogy a támogatás nem elszivárgást jelent, hanem akár helyben, akár a gazdaság más pontjain teljesítményt és állami bevételt is eredményez (nem is beszélve a kutatói kíváncsiságról: itt kaphatunk már értékelhető és nemzetgazdasági szinten is érzékelhető eredményeket). A Magyar Fesztivál Szövetség 2017-es adatai szerint a regisztrált fesztiválok fele kis- és közepes méretü, egyharmada minifesztivál (MFSZ [2017]). A kis- és közepes rendezvények mérésével tehát a fesztiválok többségére jellemző adatokhoz juthatunk.

A vizsgálatba bevont fesztiválokat úgy választottuk ki, hogy minden magyarországi régióból legyen legalább egy; a vizsgált rendezvények közül legalább egy olyan legyen, amelyet két egymás utáni évben (2017-ben és 2018-ban) is felmérünk; a fesztiválok között legyen minél többféle (zenei, müvészeti, hagyományőrző, gasztronómiai); látogatóik száma alapján kis- vagy közepes méretűek legyenek (a kutatási szempontból is

\footnotetext{
${ }^{19}$ Ez az ESA2010-ről szóló 549/2013/EU rendelet 3.14-3.33 pontjai alapján (EU [2013]) a KSH gyakorlatában leegyszerűsítve annyit jelent, hogy a magyar statisztikai hivatal a piaci termelők közül a nem piaciak közé sorolja azt a gazdasági szereplőt, amelynek bevételei három éven keresztül legalább 50 százalékban nem fedezik a termelési költségeit. A visszasoroláshoz ugyancsak tartósan, három éven keresztül fenn kell állnia a költségek legalább felét fedező bevételnek.
} 
legnépszerűbb nagy fesztiválok ugyanis más sajátosságokkal rendelkeznek, ráadásul azokra már készültek felmérések).

A látogatói (és lakossági ${ }^{20}$ ) kérdőívekkel felmért tizennégy fesztivál közül végül nyolc esetben tudtunk teljes körü gazdasági hatáselemzést végezni. ${ }^{21}$ Ezek közül öt családi, két gasztronómiai és egy összművészeti tematikájú volt, költségvetésük 12-től 364 millió forintig terjedt. A következőkben a vizsgált nyolc fesztivál adatait, hatáselemzési eredményeit egymás mellé helyezve igyekszünk közöttük hasonlóságokat vagy éppen eltéréseket feltárni. [A részletes adatokat és eredményeket a Függelékhez tartozó, online elérhető Melléklet EF1-EF5. táblázatai tartalmazzák (lásd a 3. lábjegyzetben lévő linket).]

\section{A fesztiválok bevételei}

A 3. ábra az öt családi, két gasztro- és egy mủvészeti fesztivál (A-tól H-ig jelölt fesztivál) költségvetésének bevételi föösszegét mutatja műfaji kategóriánként, növekvő sorrendben. Jól látható, hogy a vizsgált rendezvények fele belépőjegyes. ${ }^{22}$ A nagyobbak mind ilyenek, a kicsik teljesen ingyenesek.

3. ábra

A fesztiválszervezők bruttó bevételei (fesztivál-költségvetés)

Millió forint

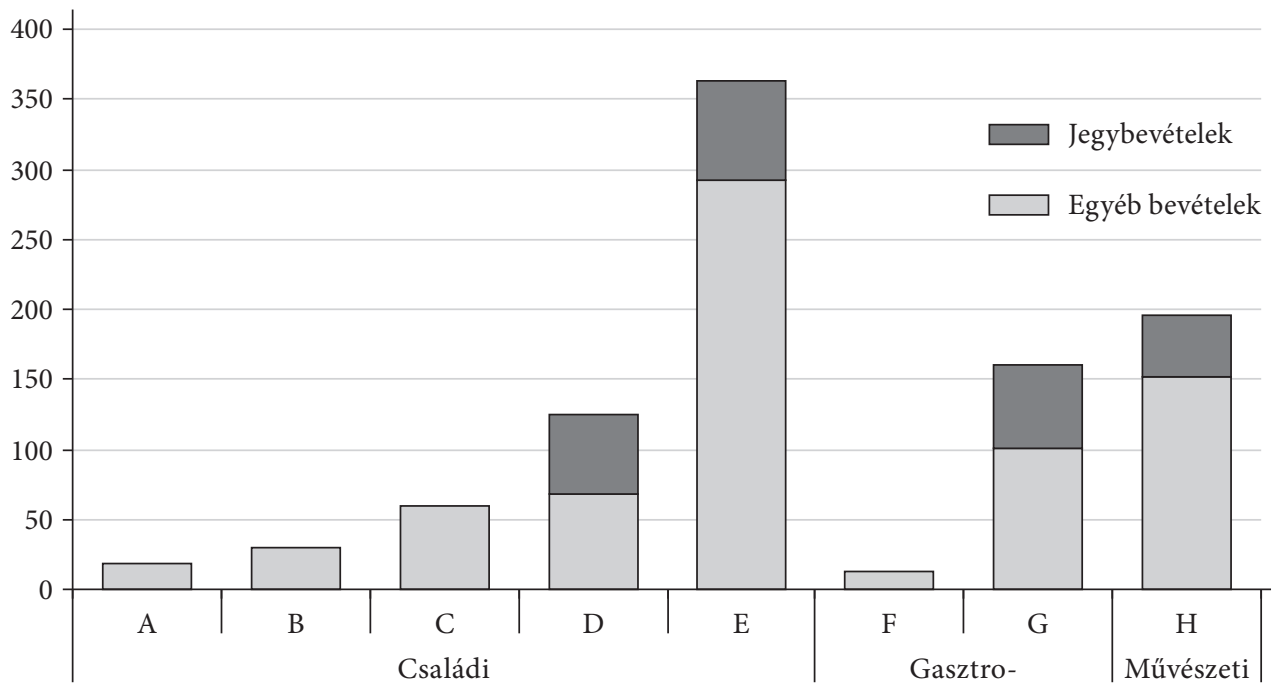

Forrás: a fesztiválszervezők és a látogatói felmérések adatai alapján saját számítás és szerkesztés.

${ }^{20}$ A lakossági adatfelvételt a társadalmi hatásvizsgálatok során használtuk, a gazdasági elemzéseknél nem. (Erről lásd részletesen Formádi-Hunyadi [2019].)

${ }^{21}$ A fesztiválok egy része elzárkózott költségvetési adatainak megadásától. Közöttük - érthető módon - nagyobb arányban voltak üzleti alapon müködő rendezvények.

${ }^{22}$ Részben fizetős fesztiválon azt értjük, hogy vannak ingyenesen és belépőjegy ellenében igénybe vehető programok vagy fesztiválnapok is. 
A kis fesztiválok bevételeinek döntő részét, 65-85 százalékát helyi vagy központi forrásból származó támogatások adják (4. ábra). A jegybevételek aránya a fizetős fesztiválok egyikénél sem éri el a költségvetés felét (a legmagasabb érték 46 százalék), s ez a rendezvény méretének növekedésével csökken (3-4. ábra).

4. ábra

A fesztiválszervezők bruttó bevételeinek szerkezete

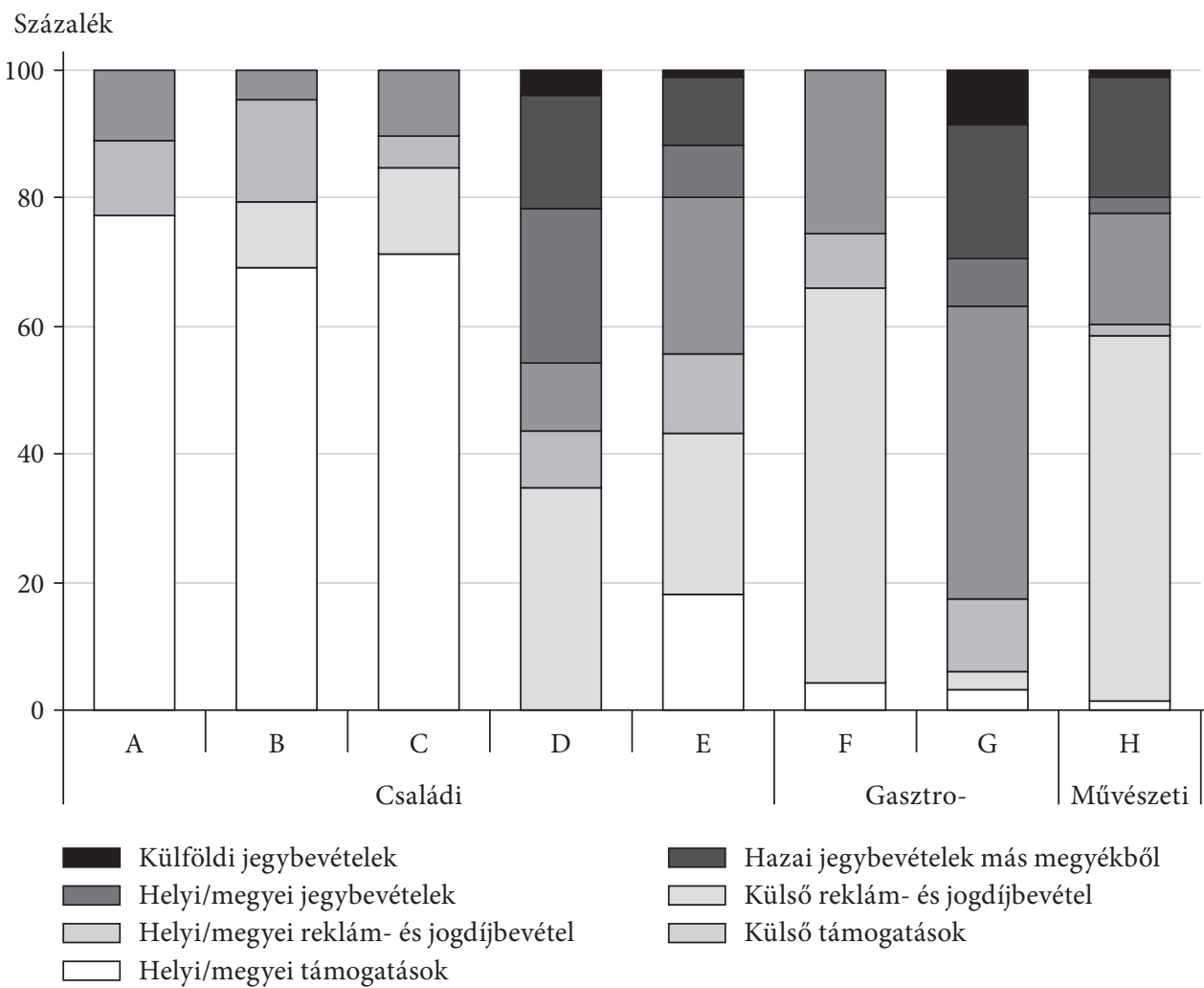

Forrás: a fesztiválszervezők és a látogatói felmérések adatai alapján saját számítás és szerkesztés.

Már az 5. ábráról is látható, hogy a fesztiválok méretének növekedésével a látogatói költések összes bevételen belüli aránya csökkenő. Ez a későbbi általánosítási lehetőségek és az ágazati hatásbecslés szempontjából fontos észrevétel.

Ha a fesztiválszervezői bevételekhez a látogatók jegyvásárláson felüli költését is hozzávesszük (5. ábra), akkor jól látható, hogy a fesztiválok által generált összes bevétel döntő részét ezek teszik ki. A kisebb rendezvényeknél a költségvetés összegét ezek nagyságrendileg is meghaladhatják. Természetesen a legnagyobb óvatossággal ezekben az esetekben kell kezelnünk a szervezők látogatónapok számára vonatkozó becsléseit.

A költések látogatók lakóhelye szerinti megoszlása a fesztivál kora, mérete, megyéje és tematikája szerint változik. A kisebb fesztiválok döntően helyiek, megyeiek által látogatottak, a bevételek legnagyobb részét az ő költésük adja. A fesztivál korának, méretének, 
5. ábra

A fesztiválok által generált összes bevétel (millió forint)

Millió forint

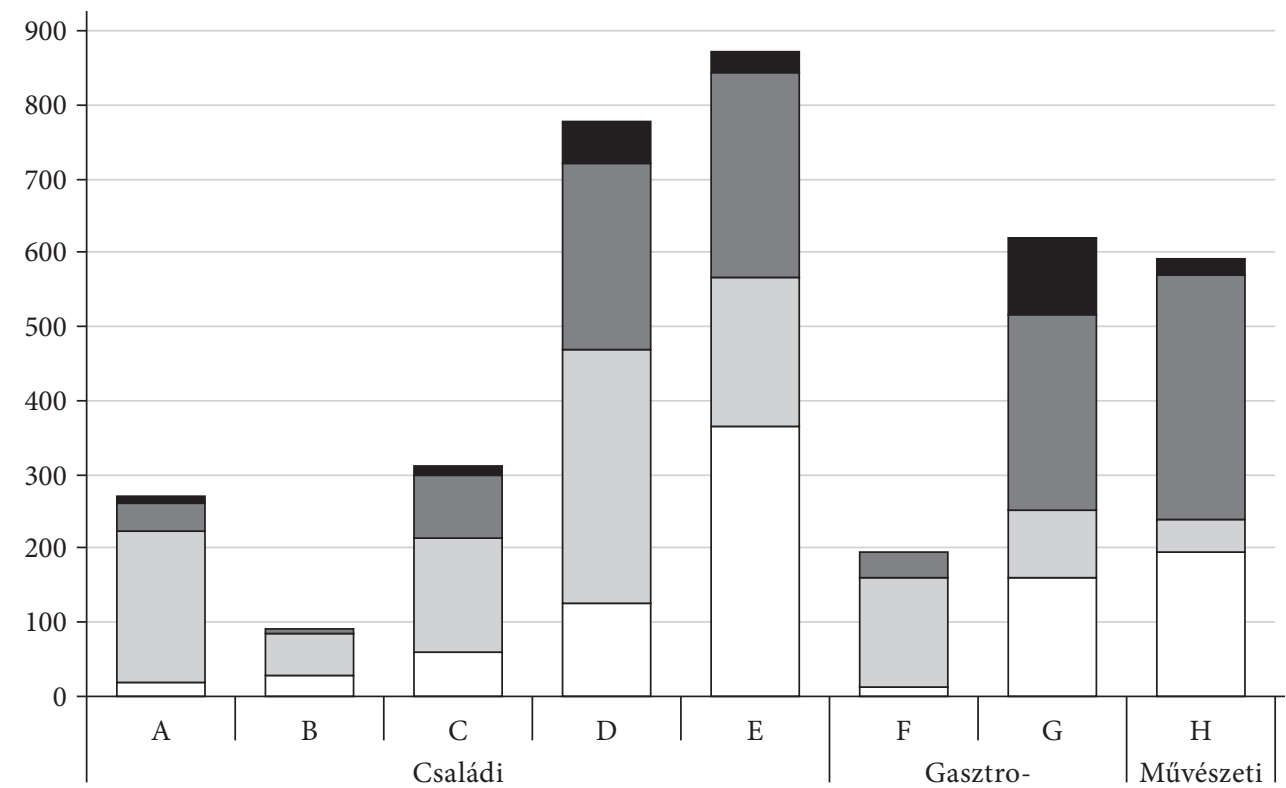

Külföldi fesztivállátogatók költése

$\square$ Más hazai megyékből érkező fesztivállátogatók költése

Helyi/megyei fesztivállátogatók költése

Fesztiválszervezői bevételek összesen (millió forint)

Forrás: a fesztiválszervezők és a látogatói felmérések adatai alapján saját számítás és szerkesztés.

ismertségének növekedésével turisztikai vonzereje is nö. Egyre nagyobb arányban jelennek meg a megyén kívüli és a határhoz közeli rendezvények esetén a külföldi vendégek is. Ezt a tematika is nagyban befolyásolja. Az általánosabb programok természetesen nemzetközileg is vonzóbbak - elsősorban a környező országokbeli látogatók számára -, mint a speciálisan magyar (nyelvü) közönséget célzó rendezvények.

\section{A látogatók kiadásai és a szervezők termelöfelhasználása}

A 6. ábra a fesztiválközönség alapárra átszámított, jegyvásárláson felüli végső fogyasztásának szerkezetét mutatja. Jól látható, hogy a kiadások túlnyomó része, 56-83 százaléka közvetlenül a szálláshely-szolgáltatás és vendéglátás ágazathoz áramlik. Az egyéb kiadások részarányát a látogatók területi összetétele (milyen arányban és mértékben kellett utazásra költeniük), valamint a fesztivál tematikája, programjai határozzák meg (az élelmiszeripari, feldolgozóipari cikkekre, egyéb művészeti, szórakoztató és sportprogramokra fordított kiadásoknál). A kereskedelem az alapárra való áttérés során az ágazatra számított árrés következtében jelent 
meg a kiadások között, ami a szállítás, közlekedés (49-es) ágazatra is hatott (a közvetlenül itt elköltött közönségkiadásokon felül is).

6. ábra

A fesztivállátogatók alapáras végső fogyasztási kiadásainak ágazati szerkezete (százalék) Százalék

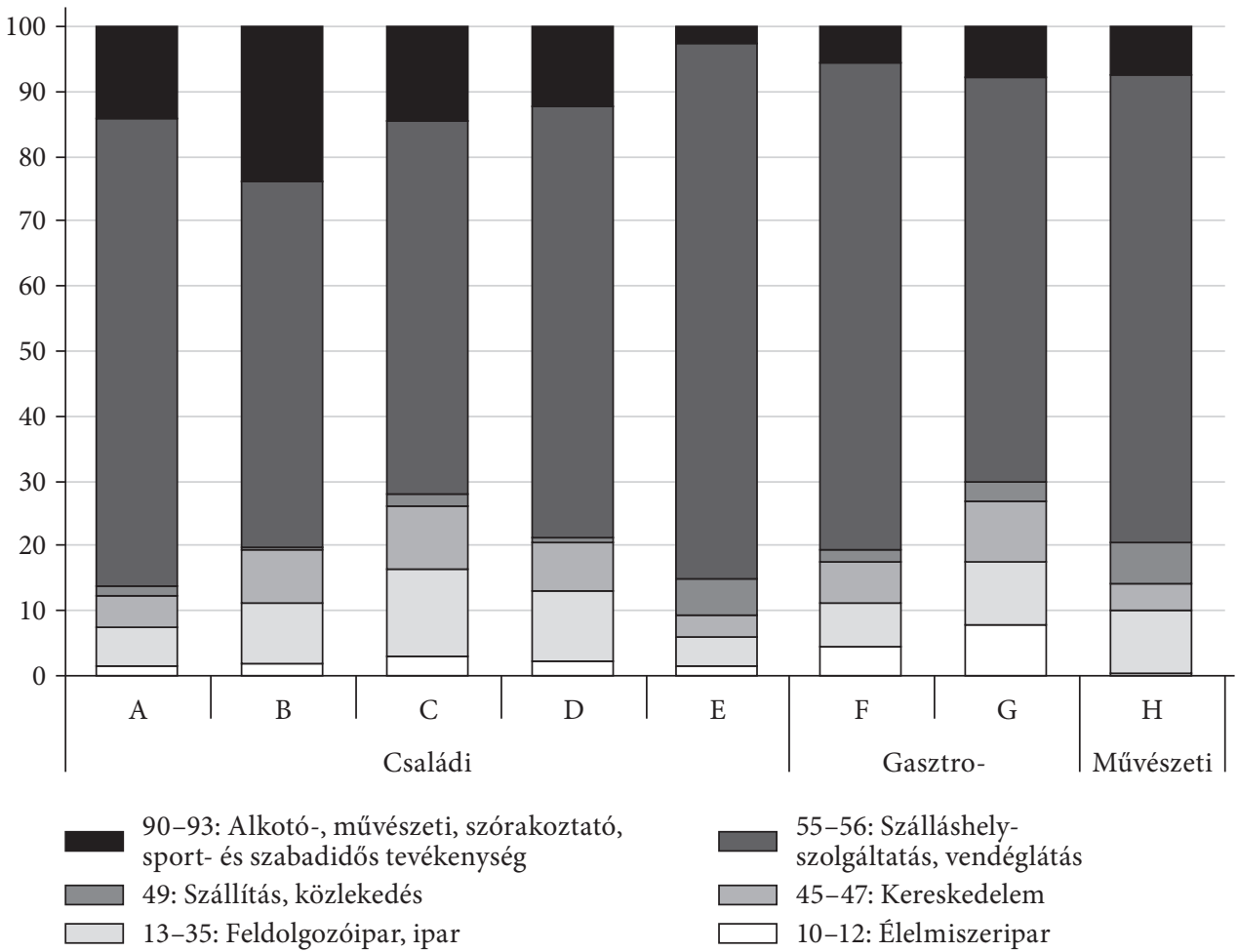

* Fesztiváljegyekkel s a fesztiválszervezőtől vásárolt más termékekkel és szolgáltatásokkal kapcsolatos kiadások nélkül.

Forrás: a fesztiválszervezők és a látogatói felmérések adatai alapján saját számítás és szerkesztés.

A szervezők termelőfelhasználásának ágazati szerkezetét vizsgálva a költségek legjelentősebb részét (több mint 55 százalékát) a fellépők, a színpad- és hangtechnika, vagyis a fesztiválmüsorral kapcsolatos ráfordítások adják. A rendezvény tematikája szerint azonban lényeges eltérések mutatkoznak. A legnagyobb, 70 százalék feletti arányt a müvészeti fesztiválok esetében mértük, a családi fesztiválok esetében ennél jó 10 százalékkal alacsonyabb, a gasztrofesztiválokéban pedig 20 százalékot sem éri el az ilyen jellegü ráfordítások aránya (lásd az online elérhető $\mathrm{Mel}$ léklet E1. táblázatát).

A gasztronómiai fesztiválok a film- és videofelvétel-gyártás és az ingatlanügyleti szolgáltatások átlagon felüli igénybevételével tünnek ki, ez azonban a vizsgált rendezvények egyedi sajátossága is lehet. Sokkal inkább sorolható az általános jellemzők közé a villamosenergia-, gáz- és vízfelhasználásuk magasabb aránya. 
A film-, video- és televízióműsor-gyártás mellett a papír- és nyomdaipari, valamint a reklám- és piackutatási megrendelések kapcsolódhatnak még a fesztivállal kapcsolatos hirdetések, a propaganda költségeihez. A reklámra önmagában is közel 9 százalékban fordított kiadások a második legjelentősebb költségtényezőt jelentik, s ha ehhez az előbbiekben felsorolt, kapcsolódó kategóriákat is hozzávesszük, akkor majdnem 15 százalékos arányt kapunk.

Jelentős tétel még (különösen a családi fesztiválok esetében) a biztonságra, védelemre, a fesztivál személyi és egészségügyi biztosítására, az áram- és vízellátásra, hulladékkezelésre fordított kiadások együttes nagysága (ez is 10 százalék felett van). A többi, nagyjából 20 százalékot képviselő ráfordítást már nem a fesztivál közvetlen megvalósításához, sokkal inkább annak előkészítéséhez, megszervezéséhez kapcsolhatjuk.

A 6. ábrán és az online elérhető Melléklet E1. táblázatában bemutatott tételek (az országos és a regionális ÁKM-eknek megfelelő ágazati bontásban) jelentik az alapját az input-output modellen alapuló multiplikátorelemzésünknek.

\section{Országos hozzáadottérték-hatások}

Először a jóval részletesebb ágazati bontású, országos input-output táblán alapuló modellszámítások eredményeit mutatjuk be. A 7. ábra az alapáras GDP-re gyakorolt hatásokat mutatja, ez fesztiválonként 30 és 378 millió forint között mozog. A nagyobb fesztiváloknak értelemszerüen jóval nagyobb a hozzáadottérték-hatása is, de a rendezvények méretéhez viszonyított arányok jelentős különbségeket mutathatnak.

7. ábra

A fesztiválok országos bruttó hozzáadottérték-hatásai (millió forint)

Millió forint

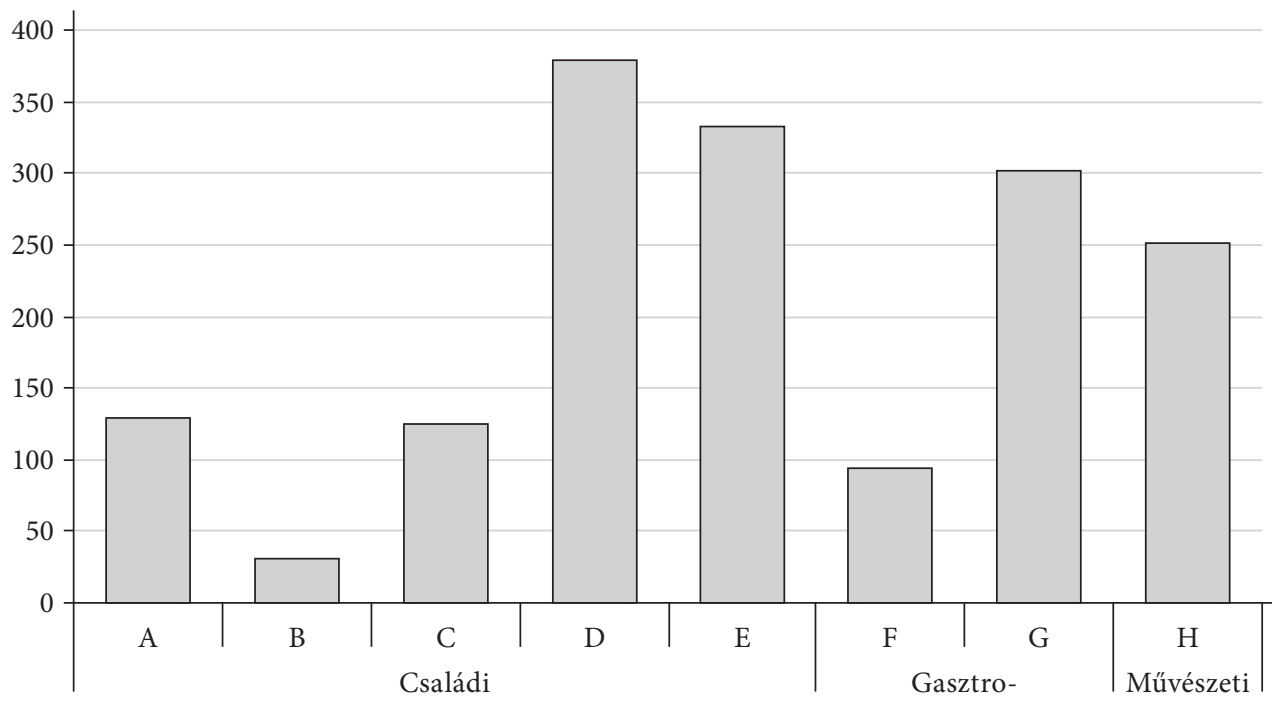

Forrás: a fesztiválszervezők és a látogatói felmérések adatai alapján saját számítás és szerkesztés. 
A hozzáadottérték-hatások belső szerkezete is fontos tanulságokkal szolgál. A 8. ábra jól mutatja, hogy a nagyobbik gasztrofesztivált leszámítva (az üzleti szemlélet itt érvényesült a leginkább) negatív a rendezvényszervezők közvetlen alapáras GDP-je. Ezt a három legkisebb családi fesztivál kivételével már a szervezők beszállítóinál jelentkező pozitív jövedelmi hatások ellensúlyozzák. Az A, B és C fesztiválok esetében azonban a látogatói költésekhez az egyéb kapcsolódó ágazatokban keletkező hozzáadott érték figyelembevétele is szükséges, hogy a teljes hatás pozitív legyen.

8. ábra

A fesztiválok országos bruttó hozzáadottérték-hatásai az érintett gazdasági szereplőknél Millió forint

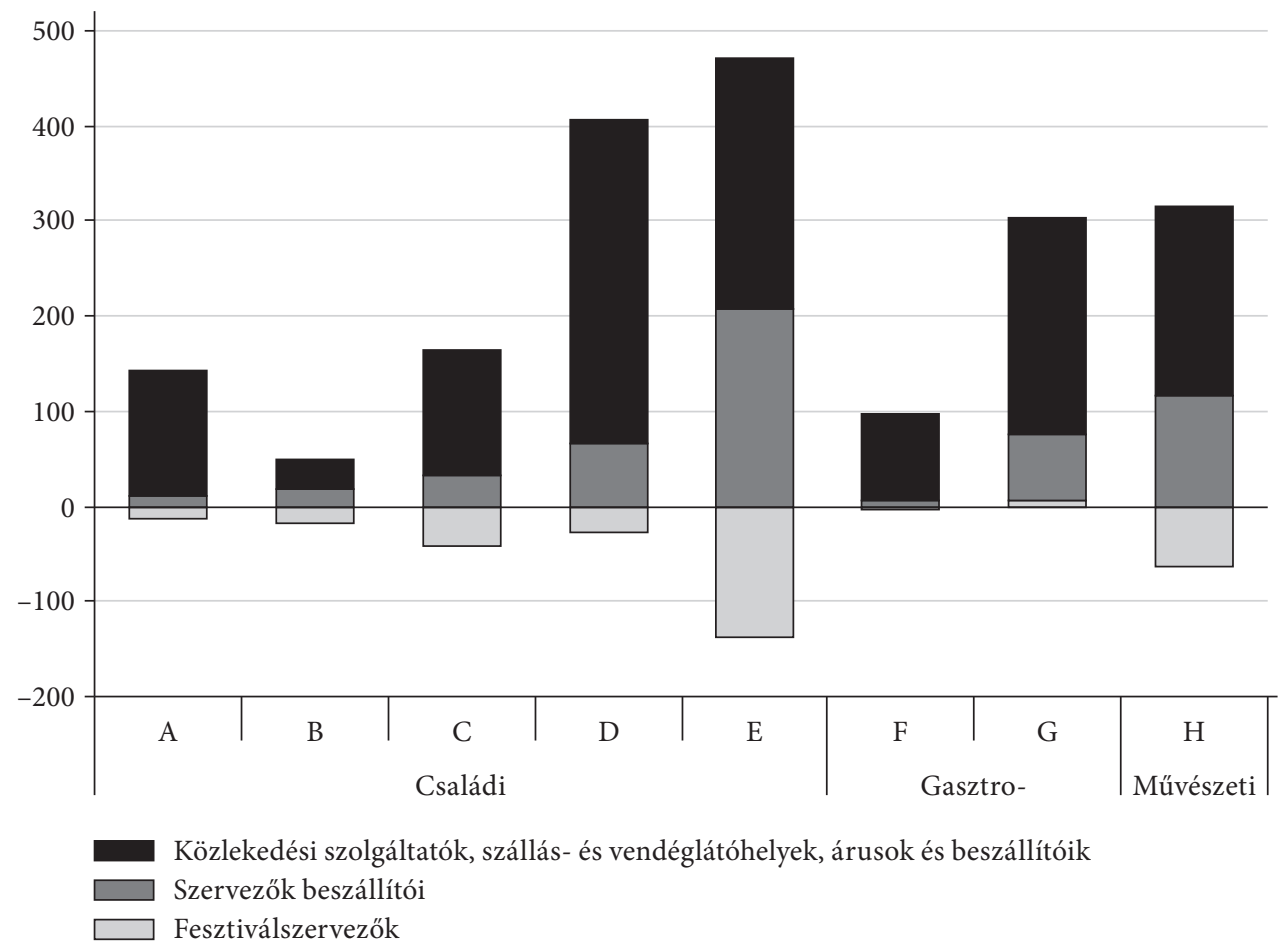

Forrás: a fesztiválszervezők és a látogatói felmérések adatai alapján saját számítás és szerkesztés.

A fesztiválok alapáras GDP-hatásait 86 százalékban a látogatói költések határozzák meg, 32 százalékos a szervezők beszállítói értékláncokon jelentkező hatásainak aránya. A szervezök negatív közvetlen bruttó hozzáadott értéke (Gross Value Added, GVA), vagyis alapáras GDP-je a teljes GVA-hatás 18 százalékát veszi el. A közvetlen és közvetett hozzáadottérték-hatások leginkább a szálláshelyeken és vendéglátósoknál (34-35 százalék), valamint az ingatlanügyletek és kereskedelem területén jelentkeznek. Az online elérhetö Melléklet E2. táblázata bemutatja a teljes hatás 95 százalékának részletes ágazati bontását. 


\section{Országos foglalkoztatási hatások}

Elöször az országos modellel számítottuk ki a foglalkoztatási hatásokat is, amelyek fesztiválonként a 9. ábrán láthatók, s 14 főtől 107 föig terjednek. Belső szerkezetük itt is jól mutatja, hogy a látogatói költések szerepe meghatározó, valamint hogy foglalkoztatási szempontból is a szálláshely-szolgáltatás és vendéglátás ágazatnál csapódik le a hatások közel 40 százaléka. A második legjelentősebb foglalkoztatási hatású ágazat a TEÁOR 90-92: Alkotó-, művészeti és szórakoztató tevékenység, amelybe maguk a szervezők és közvetlen beszállítóik is tartoznak. Jelentősek még a kiskereskedelemre, a biztonsági, építményüzemeltetési tevékenységekre tovagyürüző effektusok is. A teljes foglalkoztatási hatás részletes felbontását az online elérhető Melléklet E3. táblázata tartalmazza.

\section{9. ábra}

A fesztiválok országos foglalkoztatási hatásai az érintett gazdasági szereplőknél

Fő (FTE)

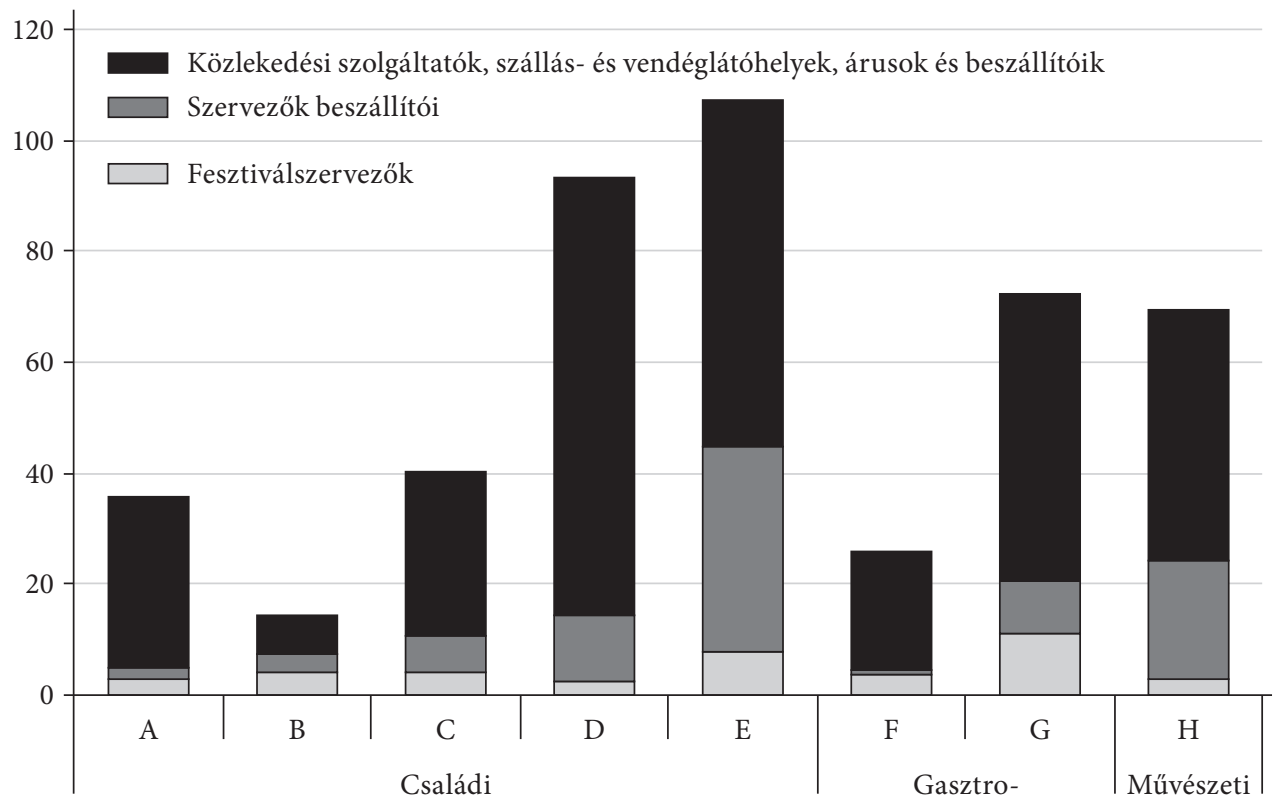

Forrás: a fesztiválszervezők és a látogatói felmérések adatai alapján saját számítás és szerkesztés.

\section{Megyei és turisztikai hatások}

Az alábbiakban a fesztivál megyéjét és az ország többi részét megkülönböztető, interregionális input-output táblákkal kapott számítások eredményeit mutatjuk be. Ezekkel számszerűsíthetők a területi és a turisztikai hozzáadottérték- és foglalkoztatási hatások. 
10. ábra

A fesztiválok megyei és turisztikai hozzáadottérték-hatásai

Millió forint

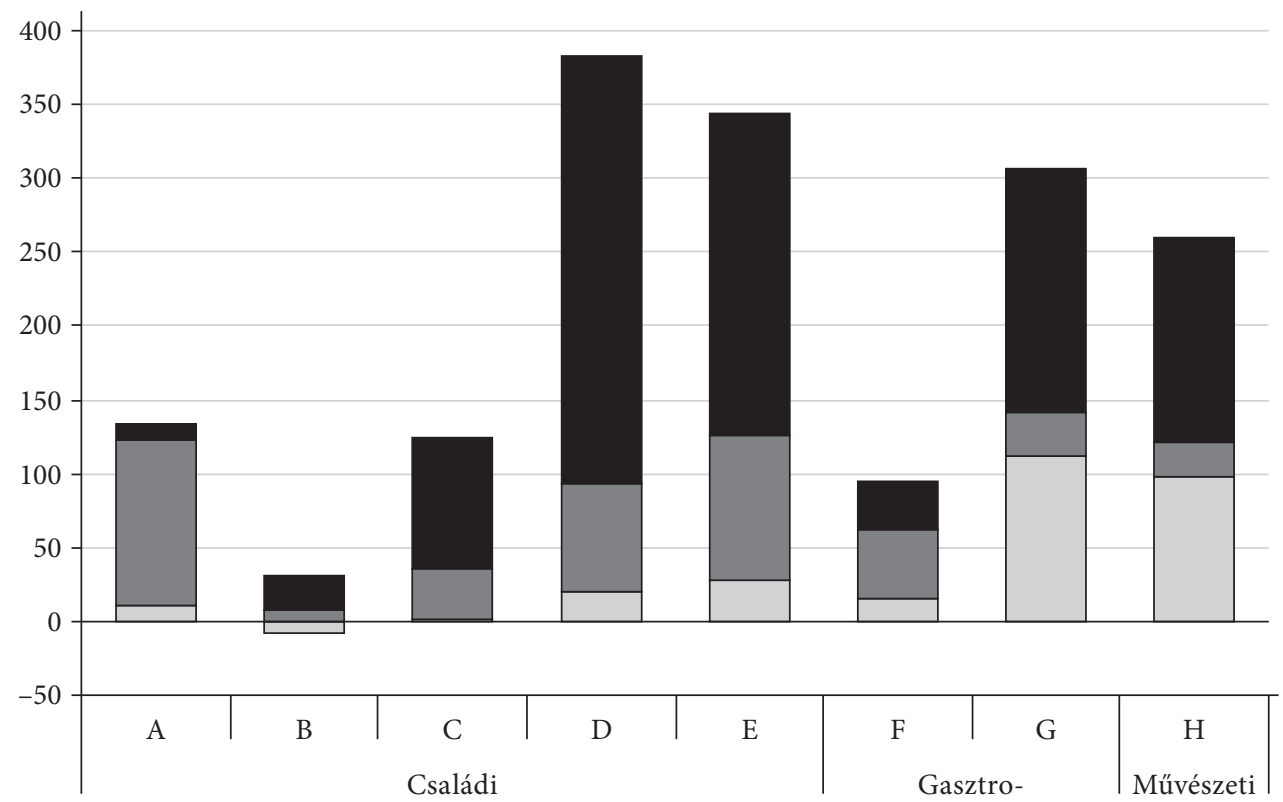

Teljes hatás megyén kívül

Helyiek költésének hatása megyén belül

Turisztikai hatás megyén belül

Forrás: a fesztiválszervezők és a látogatói felmérések adatai alapján saját számítás és szerkesztés.

A hozzáadott értékre kapott eredmények meglehetősen robusztusak, a nemzetgazdasági és a regionális modellekkel végzett számítások az országos eredmények (megyei és megyén kívüli hatások) tekintetében lényeges eltéréseket nem mutatnak. A foglalkoztatási hatásokra ez már nem igaz. Az országos és területi modellszámítások eltéréseit elsősorban az input-output táblák különböző aggregáltsági szintje okozza. ${ }^{23}$ A kevésbé részletes ágazati bontás például elmossa a G-H-I (Kereskedelem, szállítás, vendéglátás) csoport ágazatainak foglalkoztatási intenzitása közötti jelentős különbségeket. A G-H-I átlagos foglalkoztatási intenzitása ugyanis jóval alacsonyabb, mint a fesztiválok szempontjából oly meghatározó szálláshely-szolgáltatás és vendéglátás ágazaté. Ezért a regionális modellből adódó országos foglalkoztatási összhatások sorra elmaradnak a nemzetgazdasági input-output táblával számított eredményektől.

${ }^{23}$ A számításokat az országot területileg egyben kezelő, a megyei táblázatokkal azonos ágazati aggregáltsági szintü ( $11 \times 11$ ágazatos) modellel is elvégeztük. Az egyrégiós országos és a kétrégiós megyei (az adott megyét és az ország más területeit megkülönböztető) táblázatok között így legfeljebb egy-két százalékos eltérések adódtak az interregionális tovagyürűző (spillover) hatásokat is figyelembe vevő input-output eredmények javára. 
A 10. ábrán az oszlopok teljes magassága a területi modellből adódó országos bruttó hozzáadottérték-hatásokat mutatja. A legfelső részek (teljes ${ }^{24}$ hatás megyén kívül) elhagyásával kapjuk, hogy mekkorák a megye gazdaságában lecsapódó jövedelmek. A halványszürke oszlopok a megyén belüli látogatók jegyvásárlásai és egyéb költései nélkül számított megyei turisztikai hatásokat mutatják. Számottevő turisztikai jövedelmeket megyéje számára csak a nagyobbik gasztro- és a művészeti fesztivál generált. A B jelű családi fesztiválra vonatkozó becsléseink szerint a megyén kívülről érkező kiadások olyan csekélyek, az értékláncokon való elszivárgások pedig olyan magasak, hogy a fesztiválhoz kapcsolódó turisztikai jövedelem valószínüleg negatív.

A 11. ábra a megyei és a turisztikai foglalkoztatási hatásokat mutatja. Jól látható, hogy a megyén kívüli látogatók kiadásainak elhagyása a szükséges megyei létszámot sokkal kevésbé csökkenti, mint a hozzáadott értéket.

\section{1. ábra}

A fesztiválok megyei és turisztikai foglalkoztatási hatásai

Fő (FTE)

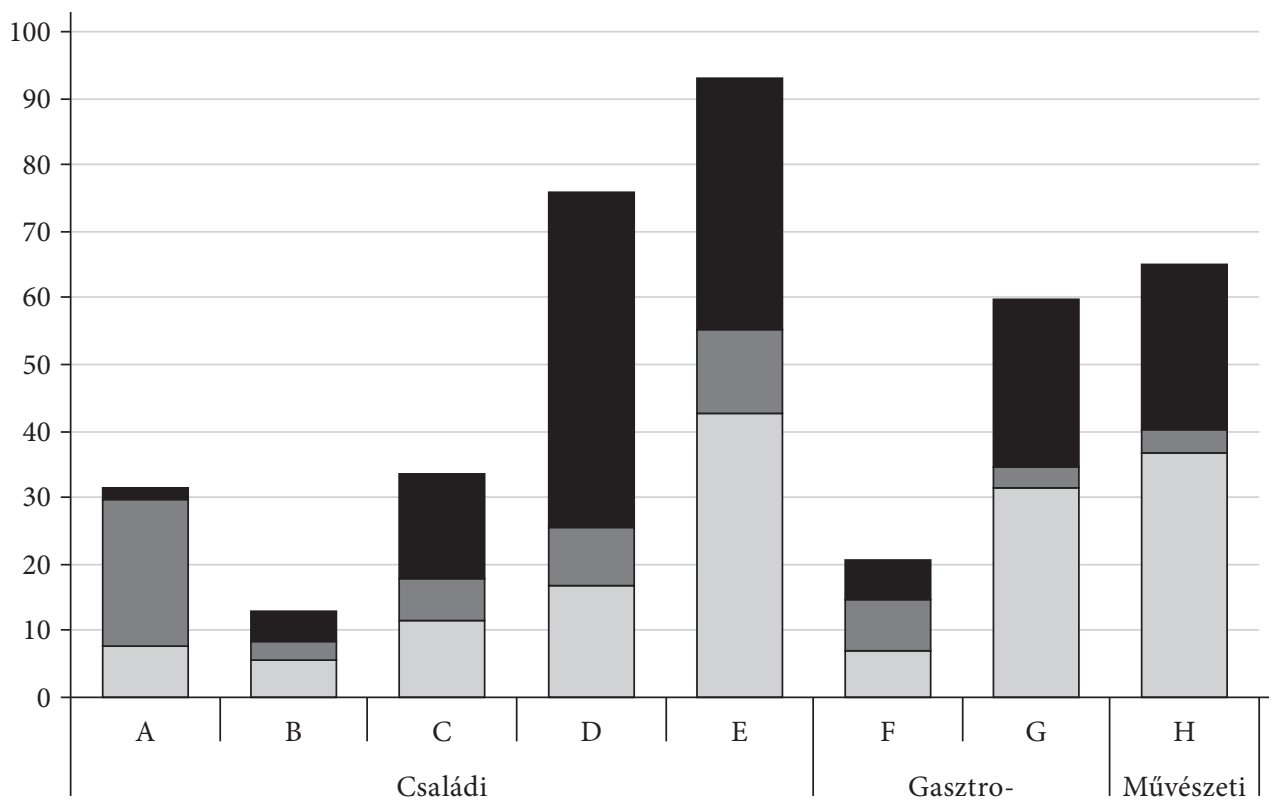

Teljes hatás megyén kívül

Helyiek költésének hatása megyén belül

Turisztikai hatás megyén belül

Forrás: a fesztiválszervezők és a látogatói felmérések adatai alapján saját számítás és a szerkesztés.

\footnotetext{
${ }^{24}$ A „teljes” jelző nem területi vonatkozásban értelmezendő, hanem úgy, hogy ez magában foglalja a közvetlen és a közvetett hatásokat is.
} 


\section{Adóhatások}

Az egyes adónemek közül az input-output modellekből származó eredmények felhasználásával a nettó termékadókra (ez közvetlenül adódott az ÁKM-ekből), a személyi jövedelemadóra, valamint a szociális hozzájárulási adóra (szocho) és az egyéni járulékokra készítettünk becslést (utóbbiakat a munkajövedelmekre kapott modellszámítások alapján). Az adóhatásokat kizárólag országos input-output modellel vizsgáltuk. Az összehasonlíthatóság érdekében a személyi jövedelemadó, a szocho és az egyéni járulékok 2017-ben érvényes általános kulcsait használtuk a 2018-ban megrendezett fesztiválok esetén is.

Az egyes fesztiválokra kapott eredmények a 12. ábrán láthatók. Az adó- és járulékbevételek legnagyobb részét mindenütt a nettó termékadók teszik ki. A nyolc fesztivál összes adóhatására 1 milliárd 181 millió forintot kaptunk.

12. ábra

A fesztiválok adó- és járulékbevételekre gyakorolt hatásai

Millió forint

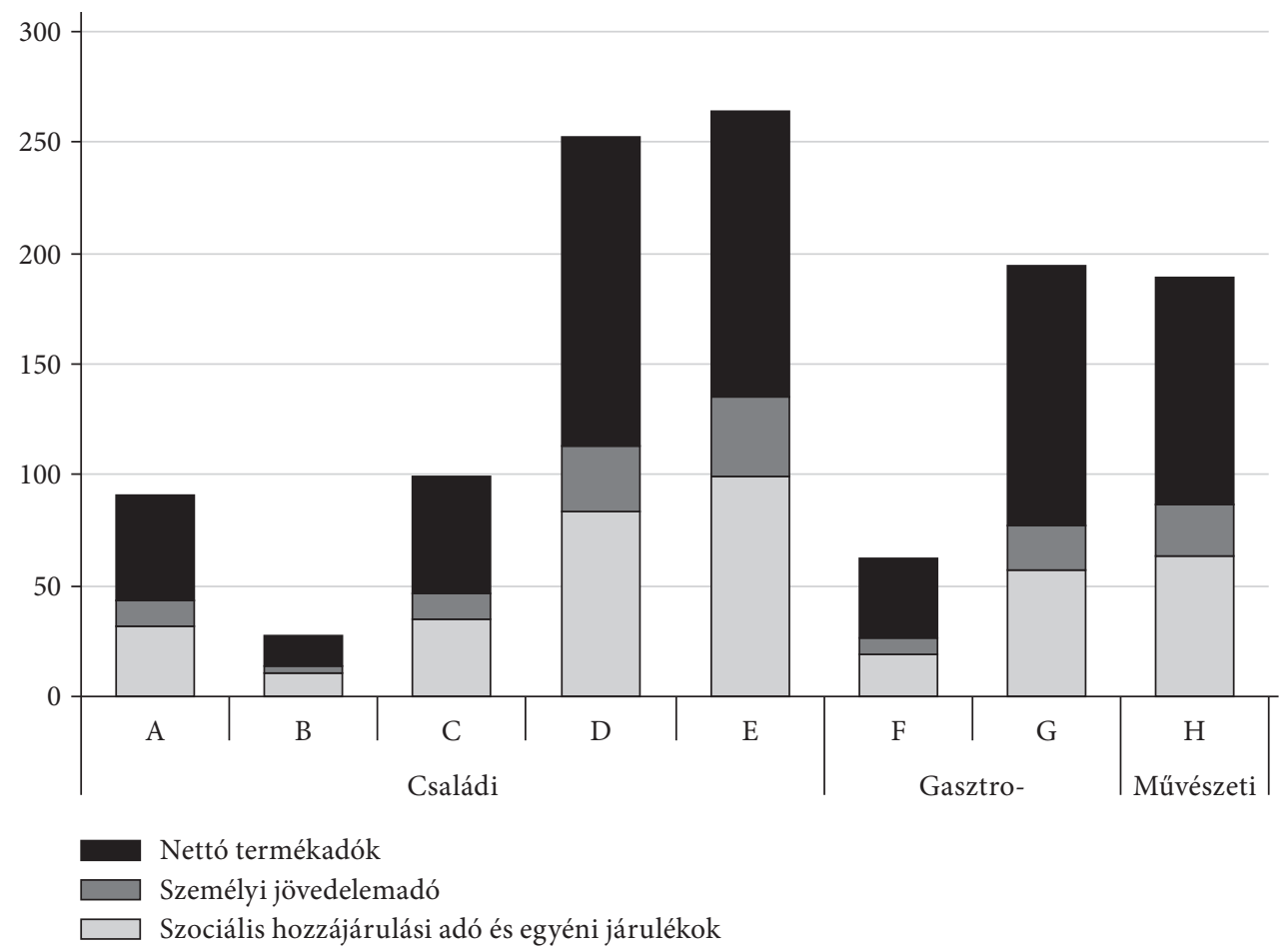

Forrás: a fesztiválszervezők és a látogatói felmérések adatai alapján saját számítás és szerkesztés. 


\section{Fesztiválmultiplikátorok}

Az egyes fesztiválok hozzáadottérték-, foglalkoztatási és adóhatásainak és összes bevételének, illetve összes támogatásának a hányadosaként úgynevezett komplex fesztiválmultiplikátorokat kaphatunk. ${ }^{25}$

A fesztiválbevételi multiplikátorokat a 3. táblázat tartalmazza. Az országos szorzók 0,33 és 0,49 között (viszonylag szük sávban, 13 százalékos relatív szórással) mozognak a 0,44-os átlagérték körül. A 0,44-es érték azt jelenti, hogy 100 forint fesztiválbevétel a vizsgált nyolc fesztivál esetében átlagosan 44 forint alapáras országos GDP-t eredményezett.

\section{3. táblázat}

Egy forint (foglalkoztatási multiplikátoroknál 1 millió forint) fesztiválbevétel gazdasági hatásai

\begin{tabular}{|c|c|c|c|c|c|c|c|c|}
\hline \multirow{2}{*}{$\begin{array}{l}\text { Fesztivál } \\
\text { kódja }\end{array}$} & \multirow{2}{*}{$\begin{array}{l}\text { Fesztivál } \\
\text { típusa }\end{array}$} & \multicolumn{3}{|c|}{ Hozzáadott érték (GVA, forint) } & \multicolumn{3}{|c|}{ Foglalkoztatás (FTE, fó) } & \multirow{2}{*}{$\begin{array}{c}\text { Adó } \\
\text { (forint })^{\star}\end{array}$} \\
\hline & & országos $^{\star}$ & megyei $^{* *}$ & $\begin{array}{c}\text { megyei } \\
\text { turisztikai }^{* *}\end{array}$ & országos $^{\star}$ & megyei $^{* *}$ & $\begin{array}{c}\text { megyei } \\
\text { turisztikai }^{* *}\end{array}$ & \\
\hline A & családi & 0,48 & 0,45 & 0,04 & 0,13 & 0,11 & 0,03 & 0,33 \\
\hline B & családi & 0,33 & 0,08 & $-0,09$ & 0,15 & 0,09 & 0,06 & 0,30 \\
\hline $\mathrm{C}$ & családi & 0,40 & 0,12 & 0,00 & 0,13 & 0,06 & 0,04 & 0,32 \\
\hline $\mathrm{D}$ & családi & 0,49 & 0,12 & 0,03 & 0,12 & 0,03 & 0,02 & 0,33 \\
\hline $\mathrm{E}$ & családi & 0,38 & 0,14 & 0,03 & 0,12 & 0,06 & 0,05 & 0,30 \\
\hline $\mathrm{F}$ & gasztro- & 0,48 & 0,32 & 0,08 & 0,13 & 0,08 & 0,04 & 0,32 \\
\hline G & gasztro- & 0,49 & 0,23 & 0,18 & 0,12 & 0,06 & 0,05 & 0,31 \\
\hline $\mathrm{H}$ & művészeti & 0,43 & 0,20 & 0,17 & 0,12 & 0,07 & 0,06 & 0,32 \\
\hline \multicolumn{2}{|c|}{$\begin{array}{l}\text { Vizsgált } \\
\text { fesztiválok együtt }\end{array}$} & 0,44 & 0,19 & 0,07 & 0,12 & 0,06 & 0,04 & 0,32 \\
\hline
\end{tabular}

* Országos input-output modell alapján.

${ }^{* *}$ Regionális input-output modell alapján.

Forrás: a fesztiválszervezők és a látogatói felmérések adatai alapján saját számítás és szerkesztés.

A megyei és a turisztikai multiplikátorok ennél jóval alacsonyabbak, átlagos értékük 0,19, illetve 0,07, s egyedi értékeik sokkal jobban szórnak. Ennek oka, hogy ezekben már a fesztiválok területi sajátosságai, az eltéréseik is megmutatkoznak.

A foglalkoztatási fesztiválmultiplikátoroknál hasonló a helyzet. Az országos, megyei és turisztikai szorzók átlagértéke rendre 0,12, 0,06 és 0,04, a területi számok szórása itt is jóval magasabb. A 0,12-os országos szorzó jelentése, hogy 1 millió

\footnotetext{
${ }^{25}$ Ilyen multiplikátorokat természetesen a munkajövedelmekre is felírhatunk. Ezeket terjedelmi okokból ebben a tanulmányban közvetlenül nem vizsgáljuk. Az előzőleg tárgyalt adóhatások egy részének számszerüsítéséhez ugyanakkor a munkajövedelem-hatások is fontos részeredményeket szolgáltattak.
} 
forintos fesztiválbevételhez a vizsgált nyolc rendezvény esetében átlagosan 0,12 fö foglalkoztatása kapcsolódott.

$\mathrm{Az}$ adómultiplikátorok értéke meglehetősen stabil, a 3. táblázat utolsó oszlopa 0,30-0,33 közötti értékeket mutat.

\section{A fesztiválágazat nemzetgazdasági jelentősége}

A magyarországi fesztiválok számával kapcsolatos bizonytalanságot a tanulmány korábbi részeiben már jeleztük, mint ahogyan azt is, hogy csak a Magyar Fesztivál Szövetség vezet viszonylag egységes, strukturált, a fesztiválok költségvetésére is kiterjedő nyilvántartást (MFSZ [2017], [2019]). Itt azonban a fesztiváloknak csak egy része regisztrált. A felmért nyolc fesztiválra vonatkozó eredményeinket mindenesetre megpróbáltuk általánosítani, s a 2019 novemberében értelmezhető költségvetési adattal nyilvántartott 293 szövetségi tagra kiterjeszteni. Fesztiválágazaton most tehát a Magyar Fesztivál Szövetség tagságát fogjuk érteni.

A 3. táblázatban láthattuk, hogy a fesztiválbevételeknek az országos bruttó hozzáadottérték-hatását kifejező multiplikátor értéke és a fesztivál összes bevétele egymástól függetlenül alakul. A fesztiválbevételek belső szerkezete és a fesztivál mérete között azonban már nem érvényesül ez a függetlenség. Ha a fesztivál méretét a látogatói költéseknél megbízhatóbb fesztiválszervezői bevételekkel (a fesztiválköltségvetéssel) mérjük, a fesztiválbevételek belső szerkezetét pedig a látogatói költések és a költségvetés hányadosával, akkor - bár a kisebb fesztiválok esetén adataink nagyon szórnak, s adatpontjaink száma is nagyon alacsony - egy a szakma képviselői által is visszaigazolt negatív irányú összefüggés valószínűsíthető: minél nagyobb a fesztivál költségvetése, általában annál kisebb az egységnyi fesztiválszervezői bevétellel elérhető látogatónapok száma, s ebből fakadóan az 1 forint költségvetésre jutó látogatói költés.

Ez a csökkenő relatív hatékonyság jelenik meg a fesztiválköltségvetéshez viszonyított bruttó hozzáadottérték-hatásban (GVA-hatásban) is. Ennek a korábbitól eltérő módon számított, úgynevezett fesztiválköltségvetési multiplikátornak az értéke látható a 13. ábrán a vizsgált nyolc fesztivál esetében a szervezői bevételek függvényében. A feltételezett negatív irányú összefüggést kétféle regressziós becsléssel is próbáltuk megragadni.

Attól tartva, hogy az A és F fesztivál kiugró értékei nem megbízhatók, vagy nem jellemzik jól a sokaságot (outlierek), s emiatt a pontokhoz illesztett logaritmikus görbe (halvány pontvonallal) talán felülbecsüli a kisebb és alulbecsüli a nagyobb fesztiválok multiplikátorait, a sötét pontvonallal meghúzott exponenciális regreszsziós görbét használtuk. ${ }^{26}$

Exponenciális regressziós függvénnyel készítettünk becslést a Magyar Fesztivál Szövetségnél regisztrált, értelmezhető költségvetési adattal nyilvántartott fesztiválokra.

${ }^{26}$ Ennek ellenére természetesen mindkettőt kipróbáltuk, sőt még a nyolc fesztiválmultiplikátor egyszerü átlagát is (ezt mutatja a halvány vízszintes pontvonal a 13. ábrán). A három közül az exponenciális függvénnyel kaptuk a legalacsonyabb, legkonzervatívabb ágazati becslést. Mivel az ágazat szerepét túlértékelni semmiképpen sem szerettük volna, utóbbit fogadtuk el a szektor egészére vonatkozó eredményként. 
13. ábra

A fesztivál-költségvetés és a hozzáadottérték-hatás kapcsolata

GVA-hatás/fesztivál-költségvetés

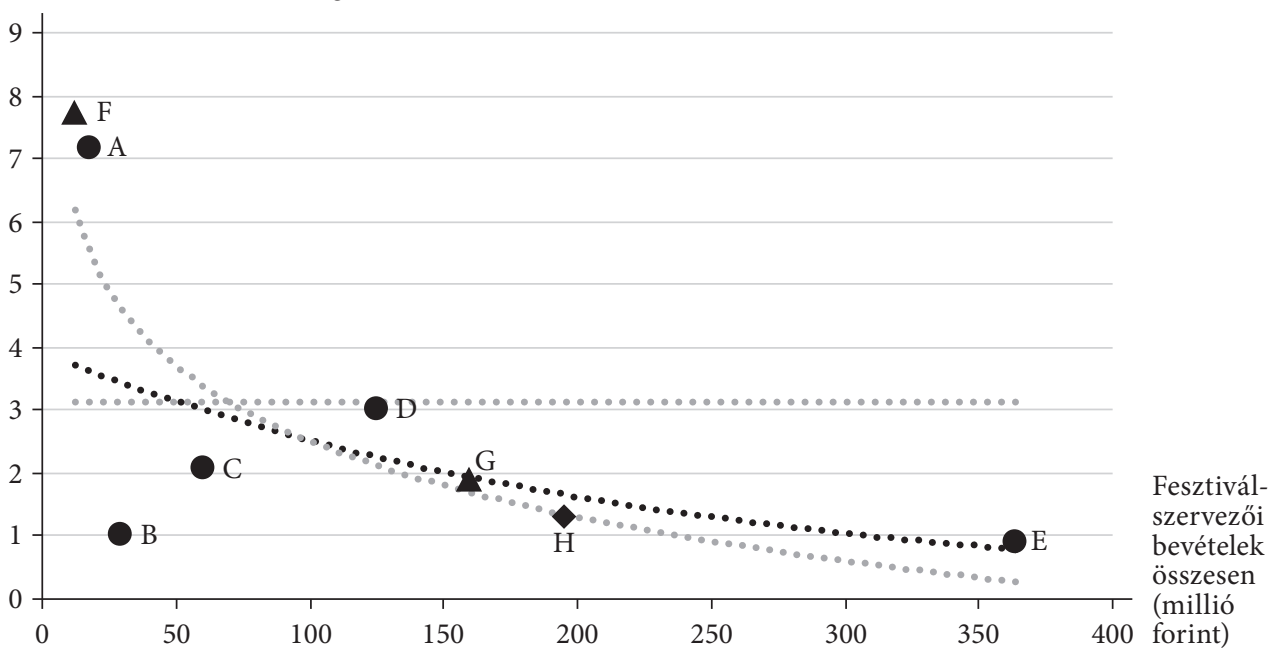

Megjegyzés: az adatpontok mellett a fesztiválok betűkódja látható. A korongok a családi, a háromszögek a gasztrokulturális, a rombusz a múvészeti fesztiválokat jelölik.

Forrás: a fesztiválszervezők és a látogatói felmérések adatai alapján saját számítás és szerkesztés.

A bruttó hozzáadottérték-hatások és a szervezői bevételek hányadosaként értelmezett fesztiválmultiplikátort a szövetség által alkalmazott költségvetési osztályközök ${ }^{27}$ mindegyikére (az osztályközepekre) meghatároztuk. Ezek és az egyes kategóriákba tartozó fesztiválok száma alapján a közel 300 rendezvény együttes hozzáadottérték-hatására majdnem 29 milliárd forint, foglalkoztatási hatására pedig több mint 8600 fö adódott (4. táblázat). (Az osztályközepek foglalkoztatási multiplikátorait ugyancsak exponenciális regresszióval, a 13. ábrán bemutatotthoz hasonló módon számítottuk.)

Becslésünk azon túl, hogy a legalacsonyabb eredményeket adó regressziós függvényeket választottuk, más szempontból is meglehetősen konzervatív. Egyrészt a fesztiválok mindegyikét piaci termelőnek tekintettük, s imputolásos módszerrel nem fedtük el a rendezvények gazdaságstatisztikában többnyire meg sem jelenő negatív közvetlen hozzáadott értékét. Nem vettük figyelembe továbbá a magasabb árszintből adódó hozzáadottérték-többletet sem. Mindezek okait korábban tárgyaltuk. Az alulbecslés legfontosabb oka mégis, hogy számításaink csak a szektor egy részére vonatkoznak. Sok fesztivál, köztük az önmagukban is jelentős hatású, számtalan külföldi vendéget vonzó megafesztiválok nem tagjai a szövetségnek. Ezek közül a 2008. évi VOLT Fesztiválra és a Balaton Soundra folyóiratban publikált felmérések is készültek (Indra

${ }^{27}$ A Magyar Fesztivál Szövetség kiadási oldaluk főösszege alapján méri a költségvetések nagyságát, szemben az általunk használt összes fesztiválbevétellel. Sem ez, sem az általunk használt bevételek bruttó jellege nem okoz azonban lényeges különbséget, hiszen a rendezvények pénzügyi formában (pénzbevételek és pénzkiadások különbségeként) meghatározott eredménye rendszerint gyakorlatilag nullszaldós. 


\section{4. táblázat}

A Magyar Fesztivál Szövetség által költségvetési adatokkal nyilvántartott fesztiválok együttes hozzáadottérték- és foglalkoztatási hatásainak becslése

\begin{tabular}{|c|c|c|c|c|c|c|}
\hline \multicolumn{2}{|c|}{$\begin{array}{l}\text { A Magyar Fesztivál Szövetség } \\
\text { adatai, 2017-2019* }\end{array}$} & \multicolumn{5}{|c|}{ Becsült adatok } \\
\hline $\begin{array}{l}\text { fesztivál- } \\
\text { költségvetés } \\
\text { (forint) }^{* *}\end{array}$ & $\begin{array}{l}\text { a költségvetési } \\
\text { osztályközbe } \\
\text { eső fesztiválok } \\
\text { száma }\end{array}$ & $\begin{array}{l}\text { osztály- } \\
\text { közép }\end{array}$ & $\begin{array}{l}\text { fesztivál- } \\
\text { költségvetési } \\
\text { GVA- } \\
\text { multiplikátor }\end{array}$ & $\begin{array}{l}\text { GVA-hatás } \\
\text { (millió } \\
\text { forint) }\end{array}$ & $\begin{array}{c}\text { Fesztivál- } \\
\text { költségvetési } \\
\text { foglalkoztatási } \\
\text { multiplikátor } \\
\text { (fő/millió forint) }\end{array}$ & $\begin{array}{l}\text { Foglal- } \\
\text { koztatási } \\
\text { hatás } \\
\text { (fö, FTE) }\end{array}$ \\
\hline 100 millió felett & 25 & 300 & 1,05 & 7845 & 0,30 & 2227 \\
\hline 50-100 millió & 30 & 75 & 2,81 & 6333 & 0,85 & 1904 \\
\hline 20-50 millió & 76 & 35 & 3,36 & 8928 & 1,02 & 2711 \\
\hline 10-20 millió & 66 & 15 & 3,67 & 3629 & 1,12 & 1107 \\
\hline 5-10 millió & 64 & 7,5 & 3,79 & 1818 & 1,16 & 556 \\
\hline 1-5 millió & 26 & 3 & 3,86 & 301 & 1,18 & 92 \\
\hline 1 millió alatt & 6 & 0,5 & 3,91 & 12 & 1,20 & 4 \\
\hline Összesen & 293 & & & 28866 & & 8601 \\
\hline
\end{tabular}

${ }^{*}$ 2019. november.

** A fesztivál teljes kiadása.

Forrás: a Magyar Fesztivál Szövetség (MFSZ [2019]), a kutatásban részt vett fesztiválok és a látogatói felmérések adatai alapján saját számítás és szerkesztés.

[2009]), ${ }^{28}$ illetve a legnagyobbnak számító Sziget Fesztivál látogatói és költségvetési adatairól is rendszeresen cikkeznek az újságok (Libor-Kocsis [2018], Marnitz [2019]). Ha csak ezt a további három fesztivált a sajtóból és a szervező cég számviteli beszámolójából ismert értékei alapján a legegyszerűbb számítással hozzávennénk a vizsgált körhöz, az ágazati GVA-becslési eredményünk legalább 40 milliárd forintra ugrana. De a teljes fesztiválágazat gazdasági jelentősége a figyelembe nem vett további rendezvények miatt minden bizonnyal ezt a mértéket is jóval meghaladná.

$S$ bár a kapott eredmények a nemzetgazdaság teljes éves hozzáadott értékének, valamint foglalkoztatotti létszámának még így is csupán 0,1-0,2 százalékát adnák, a fesztiválok néhány napos időtartamuk alatt is képesek a hivatalos gazdaságstatisztika által valóban számon tartott, a kisebb ágazatok éves teljesítményével összemérhető hatásokat generálni. Ha az ágazatok hatásait a végső keresletük által a gazdaság egészében (tehát nemcsak közvetlenül a vizsgált szektorban, hanem a tovagyürüző hatások következtében más ágazatokban is) létrejövő hozzáadott értékkel és megvalósuló foglalkoztatással mérjük (ez teljesen kompatibilis azzal, ahogyan a fesztiválok hatásait kifejeztük), akkor a Magyar Fesztivál Szövetség tagjaival megragadott fesztiválszektor nagysága a 14. ábra alapján leginkább az utazásközvetítés, utazásszervezés ágazatéhoz hasonló.

\footnotetext{
${ }^{28}$ Lásd még Sziget Kulturális Menedzser Iroda Zrt. éves beszámolói, kiegészítő mellékletei, 2017-2018.
} 
14. ábra

Ágazatok hozzáadottérték- és foglalkoztatási hatásai

A) Ágazatok hozzáadottérték-hatásai (milliárd forint)

30: Egyéb jármű gyártása

02: Erdőgazdálkodás

53: Postai és futárpostai tevékenység

73: Reklám és piackutatás

95: Számítógép, személyi és háztartási cikk javítása

79: Utazásközvetítés, utazásszervezés és egyéb foglalás

Fesztiválszervezés*

05-09: Bányászat és kőfejtés

18: Nyomdai és egyéb sokszorosítási tevékenység

66: Egyéb pénzügyi tevékenység

78: Munkaerőpiaci szolgáltatás

50: Vízi szállítás

97-98: Háztartási alkalmazottat foglalkoztató magánháztartás; háztartás termék-előállítása, szolgáltatása saját fogyasztásra

03: Halászat és halgazdálkodás
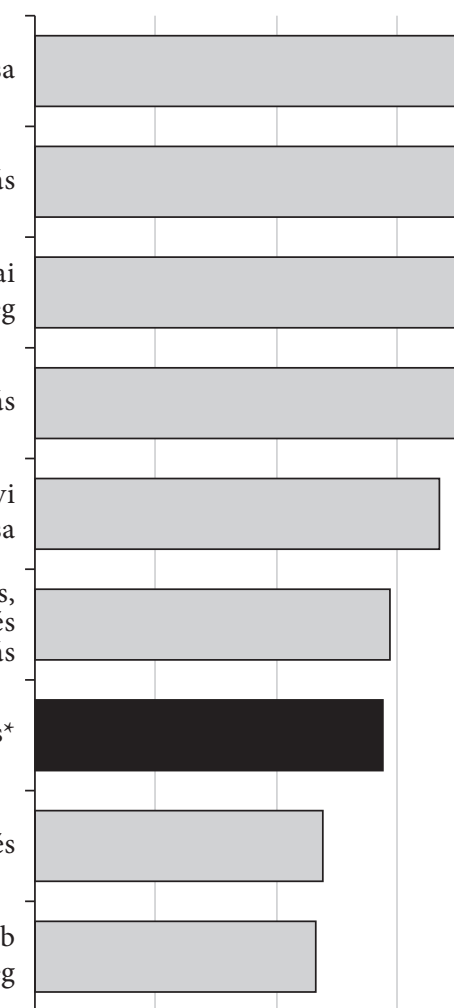

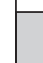

\section{$-$}

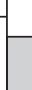

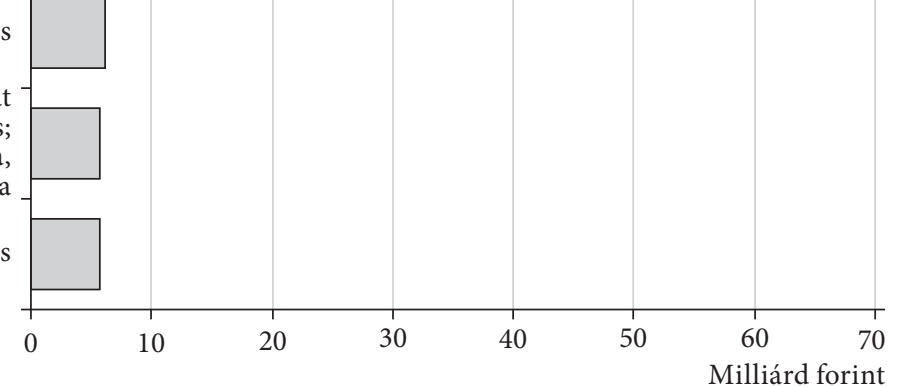

* A Magyar Fesztivál Szövetségnél 2019 novemberében költségvetési adatokkal nyilvántartott 293 fesztivál becsült hozzáadottérték-hatása.

Forrás: a Központi Statisztikai Hivatal, a Magyar Fesztivál Szövetség (MFSZ [2019]), a kutatásban részt vett fesztiválok és a látogatói felmérések adatai alapján saját számítás és szerkesztés. 


\section{A 14. ábra folytatása}

B) Ágazatok foglalkoztatási hatásai (ezer fö)

58: Kiadói tevékenység 59-60: Film, videó, televízió-műsor gyártása, hangfelvétel kiadása; műsor-összeállítás és műsorszolgáltatás

33: Gép, berendezés és eszköz javítása és üzembe helyezése

17: Papír és papírtermék gyártása

02: Erdőgazdálkodás

53: Postai és futárpostai tevékenység

77: Kölcsönzés és operatív lízing

19: Kokszgyártás és kőolaj-feldolgozás

Fesztiválszervezés*

30: Egyéb jármű gyártása

95: Számítógép, személyi és háztartási cikk javítása

79: Utazásközvetítés, utazásszervezés és egyéb foglalás 97-98: Háztartási alkalmazottat foglalkoztató magánháztartás;

háztartás termék-előállítása, szolgáltatása saját fogyasztásra

73: Reklám és piackutatás

18: Nyomdai és egyéb sokszorosítási tevékenység

78: Munkaerőpiaci szolgáltatás

66: Egyéb pénzügyi tevékenység

05-09: Bányászat és kőfejtés

51: Légi szállítás

50: Vízi szállítás

03: Halászat és halgazdálkodás
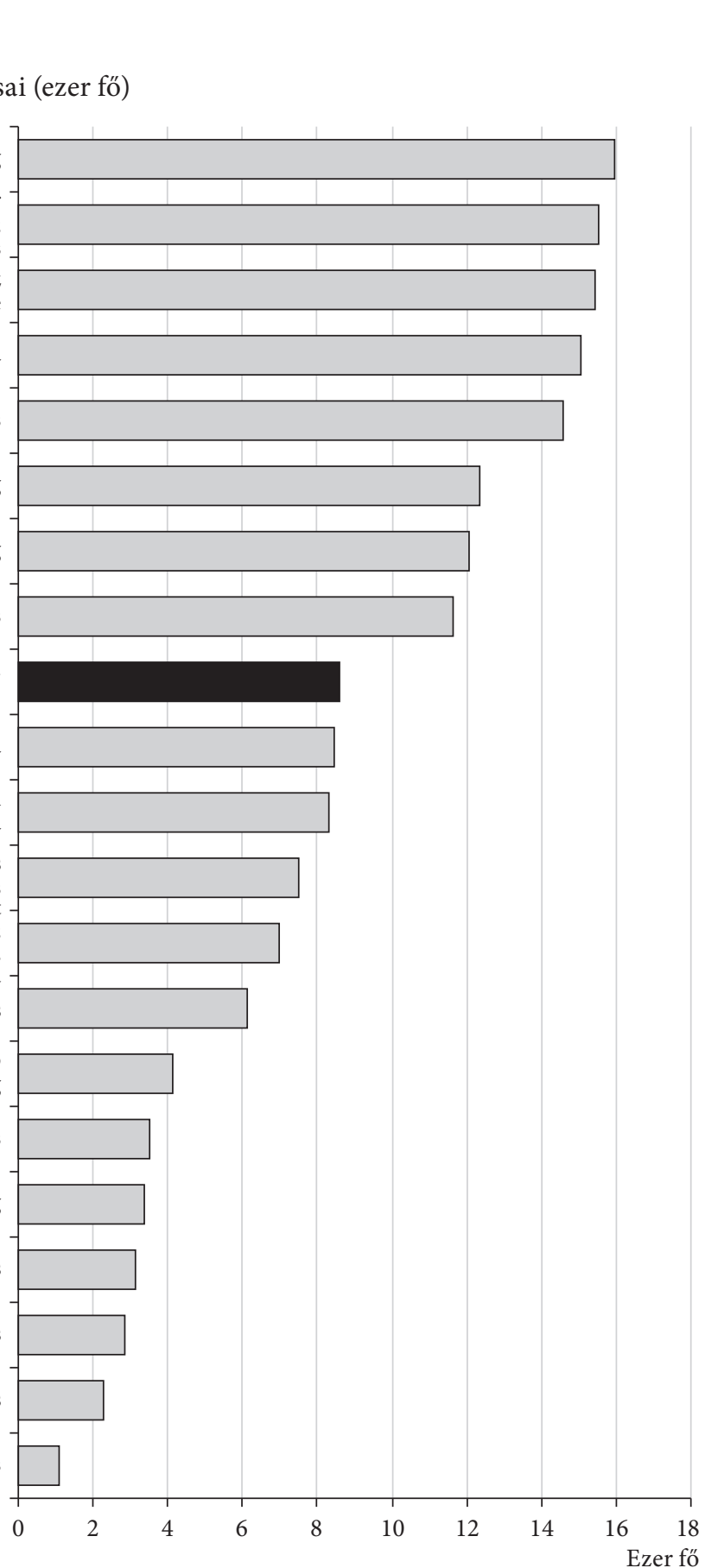

* A Magyar Fesztivál Szövetségnél 2019 novemberében költségvetési adatokkal nyilvántartott 293 fesztivál becsült foglalkoztatási hatása.

Forrás: a Központi Statisztikai Hivatal, a Magyar Fesztivál Szövetség (MFSZ [2019]), a kutatásban részt vett fesztiválok és a látogatói felmérések adatai alapján saját számítás és szerkesztés. 


\section{Összefoglalás}

Tanulmányunk nyolc hazai fesztivál gazdasági hatásainak összehasonlító elemzését mutatta be. Eredményeink mögött egy hároméves, összesen tizennégy fesztiválra kiterjedő projekt áll. Rendelkezésre álló adataink öt családi, két gasztrokulturális és egy összművészeti fesztivál esetében tették lehetővé a tanulmányban bemutatott teljes körű gazdasági hatáselemzést. A vizsgált nyolc fesztivált 2017-ben és 2018-ban rendezték meg, költségvetésük pár tízmillió forinttól több száz millióig terjedt. A szervezők bevételeit, kiadásait, az általuk foglalkoztatottak számát, az értékesítési helyet bérlő vendéglátósok és árusok számát, megyei megoszlását és a látogatók rendezők által becsült számát számítógépes ürlapokkal, a vezetőkkel, gazdasági ügyekért felelős munkatársakkal folytatott mélyinterjúk, szakmai konzultációk során mértük fel. A fesztivállátogatói költéseket helyszíni, személyes megkérdezésen alapuló kérdőíves felmérésekkel, rövid, a látogatók demográfiai adataira vonatkozó, valamint részletes, költésük termék- és szolgáltatáscsoportok szerinti szerkezetére is kitérő lekérdezéssel vizsgáltuk.

A hatáselemzést országos és regionális input-output táblákkal és multiplikátorokkal végeztük. Az input-output módszer alkalmazása során a látogatói költésekre és a szervezői kiadásokra nem új keresletként tekintettünk, hanem az adott év végső fogyasztási kiadásaiban és termelőfelhasználásában már elszámolt, a hivatalos gazdaságstatisztika által nyilvántartott tételekként. Ily módon ezek hatásai is benne vannak az adott év nemzetgazdasági teljesítményében, a fesztiválok által érintett ágazatok kibocsátásában, hozzáadott értékében és foglalkoztatásában. Eredményeink tehát nem úgy értelmezendők, hogy a fesztiválok következtében a kimutatott mértékben nőtt, vagy újbóli megrendezésük esetén ennyivel nőne a gazdaság teljesítménye. A kapcsolódó kereslet (vagy ennek egy része) lehet, hogy fesztiválok nélkül is felmerült volna vagy felmerülne, hasonló vagy akár teljesen eltérő ágazati szerkezetben és összegben. ${ }^{29}$ A kiadások alternatív felhasználási lehetőségeit nem ismerjük, s így ezek hatásait sem tudtuk felmérni. A tanulmányban közölt adatok és modellszámítások helyes, expost szemléletủ értelmezése ezért sokkal inkább az, hogy az adott évben az egyes fesztiválokhoz kapcsolódóan becsléseink szerint a közölt mértékü és összetételü kiadások valósultak meg, s ezek közvetlen és tovagyürűző hatásai a kalkulált számok szerinti részt képviselnek az országos és a megyei gazdasági teljesítménymutatókban.

A nyolc fesztivál együttes országos hozzáadottérték-hatása számításaink alapján meghaladja az 1,6 milliárd Ft-ot, teljes munkaidejü egyenértékes létszámmal mért foglalkoztatási hatásuk 400-450 fő körüli, a szociális hozzájárulási adót és az egyéni járulékokat, a személyi jövedelemadót és a nettó termékadókat is magában foglaló adóhatásukat pedig 1,1-1,2 milliárd Ft-ra becsüljük. A számviteli értelemben ugyan egytől egyig nagyjából nullszaldós fesztiválok piaci termelőként számított közvetlen hozzáadott értéke rendszerint negatív (a nyolc fesztivál együttes adatai

\footnotetext{
${ }^{29}$ A külföldi látogatók költéseiről persze nehezen állítható, hogy az adott fesztivál nélkül is azonos szinten megtörténtek volna (egyes külföldi turisták meglehet, hogy a fesztivál nélkül egyáltalán nem látogattak volna hazánkba), illetve a belföldi háztartások fogyasztásának importhányada miatt kétségbe vonható lenne az az állítás is, hogy a fesztivállal kapcsolatban megvalósult belföldi kereslet teljes egészében belföldi keresletként jelentkezett volna a fesztivál hiányában is.
} 
alapján az összes bruttó hozzáadottérték-hatás (GVA-hatás) -18\%-a), a szervezők által igénybe vett szolgáltatások (32\%) és főként a látogatói költések tovagyürüző hatásai (86\%) azonban ezt jócskán ellensúlyozzák. A fesztiválszervezők tevékenysége tehát közvetlenül nem növeli, hanem inkább csökkenti a bruttó hozzáadott értéket (GVA). Ez akár indoka is lehet annak, hogy a gazdaságstatisztika miért nem kezeli külön gazdasági tevékenységként és ágazatként a fesztiválszervezést. Közvetett hatásaik és a fesztiválokon megvalósult költések azonban jelentős mértékü pozitív hozzáadott értéket termelnek.

A rendezvények megyei és turisztikai hatásai erősen függnek a látogatók, az értékesítő vendéglátók, árusok, valamint a fellépők és a szervezők más beszállítóinak területi megoszlásától. Jelentősebb turisztikai hatást a vizsgált fesztiválok közül csak kettőnél mutattunk ki. Előfordult viszont olyan rendezvény is, ahol becsléseink szerint a megyén kívülről érkező kiadások olyan csekélyek, az értékláncokon való elszivárgások pedig olyan magasak, hogy a fesztiválhoz kapcsolódó nettó megyei jövedelem valószínüleg negatív.

A fesztiválok jövedelemtermelő képessége szempontjából a látogatók jegyeken felüli (ha van egyáltalán belépő) költekezésének van döntő jelentősége. Ez pedig a látogatók (látogatónapok) számától és az egy látogatónapra jutó költésektől függ. Kérdőíves adatfelvételeinek tapasztalatai alapján utóbbiak viszonylag megbízhatóan mérhetők, a látogatók szervezők által becsült számában viszont meglehetősen nagy a bizonytalanság. Ennek csökkentésében a látogatószámlálás fejlett informatikai módszerekkel, drónos, arcfelismerö és mozgáskövető hardver- és szoftvereszközökkel történő támogatása segíthet.

A felmért nyolc fesztiválra vonatkozó eredményeink általánosításának, a fesztiválszektorra való kiterjesztésének lehetőségeit is megvizsgáltuk. Bár - ahogy a tanulmányban többször is említésre került - a gazdaságstatisztika ilyen ágazatot nem tart számon, mi mégis arra voltunk kíváncsiak, hogy mekkora lehet a szektor nemzetgazdasági jelentősége más ágazatokkal való összehasonlításban.

A hozzáadottérték- és a foglalkoztatási hatások, valamint az összes fesztiválbevétel hányadosaként úgynevezett fesztiválmultiplikátorokat számítottunk, amelyek értéke fesztiválonként ugyan eltérő, de a 0,44-os átlagérték körül, egy viszonylag szűk sávban mozog, s nincs összefüggésben a fesztivál összes bevételével. A fesztiválbevételek belső szerkezete és a fesztivál mérete között már nem érvényesül ez a függetlenség. Ha a fesztivál méretét a látogatói költéseknél jóval megbízhatóbb fesztiválszervezői bevételekkel (a fesztivál-költségvetéssel) mérjük, a fesztiválbevételek belső szerkezetét pedig a látogatói költések és a költségvetés hányadosával, akkor - bár a kisebb fesztiválok esetén adataink nagyon szórnak, s adatpontjaink száma is nagyon alacsony - egy a szakma képviselöi által is visszaigazolt, negatív irányú összefüggés valószínüsíthető: minél nagyobb a fesztivál költségvetése, általában annál kisebb az egységnyi fesztiválszervezői bevétellel elérhető látogatónapok száma, és ebből fakadóan az 1 Ft költségvetésre jutó látogatói költés. Ez a csökkenő relatív hatékonyság jelenik meg a fesztiválköltségvetéshez viszonyított bruttó hozzáadottérték-hatásban is.

Számításainkat kiterjesztettük a Magyar Fesztivál Szövetségnél regisztrált, értelmezhetö költségvetési adattal nyilvántartott fesztiválokra. A bruttó hozzáadottérték-hatások 
és a szervezői bevételek hányadosaként értelmezett fesztiválmultiplikátort a szövetség által alkalmazott költségvetési kategóriák mindegyikére megbecsültük. Ezek és az egyes kategóriákba tartozó fesztiválok száma alapján a közel 300 rendezvény együttes hozzáadottérték-hatása majdnem 29 milliárd Ft, foglalkoztatási hatása pedig több mint 8600 fö.

Becslésünk több szempontból is meglehetősen konzervatív: a fesztiválok mindegyikét gazdaságstatisztikai értelemben piaci termelőnek tekintettük, s számításaink csak a szektor egy részére vonatkoznak. Sok fesztivál, köztük az önmagukban is jelentős hatású, rengeteg külföldi vendéget vonzó megafesztiválok nem tagjai a szövetségnek. Mindezek miatt a teljes fesztiválágazat gazdasági jelentősége minden bizonnyal jóval meghaladja az itt közölt mértéket. S bár a nemzetgazdaság teljes éves hozzáadott értékének, valamint foglalkoztatotti létszámának a kapott eredmények csupán 0,1-0,2 százalékát adják, a fesztiválok pár napos időtartamuk alatt is képesek a hivatalos gazdaságstatisztika által valóban számontartott, kisebb ágazatok éves teljesítményével összemérhető hatásokat generálni. Ezek nagysága leginkább az utazásközvetítés, utazásszervezés ágazatéhoz hasonló.

\section{Hivatkozások}

Ambargis, Z. O.-Mead, C. I. [2012]: RIMS II. An essential tool for regional developers and planners. Bureau of Economic Analysis, Washington, DC, https://www.bea.gov/sites/ default/files/methodologies/RIMSII_User_Guide.pdf.

Armstrong, H. W. [1993]: The Local Income and Employment Impact of Lancaster University. Urban Studies, Vol. 30. No. 10. 1653-1668. o. https://doi.org/10.1080/00420 989320081641.

BABBIE, E. [2017]: A társadalomtudományi kutatások gyakorlata. Balassi Kiadó, Budapest.

Batey, P. W. J.-Madden, M.-Scholefield, G. [1993]: Socio-economic Impact Assessment of Large-scale Projects using Input-Output Analysis: A Case Study of an Airport. Regional Studies, Vol. 27. No. 3. 179-191. o. https://doi.org/10.1080/00343409312331347485.

Billings, R. B.-KatZ, J. L. [1982]: A technique to obtain accurate impact multipliers for individual firms by means of existing input-output models. Environment and Planning A: Economy and Space, Vol. 14. 739-744. o. https://doi.org/10.1068/a140739.

BRÁVÁCz Ibolya [2019]: A fesztiválok gazdasági, társadalmi hatásai és mérési módszerei. Prosperitas, 6. évf. 4. sz. 59-77. o. http://dx.doi.org/10.31570/Prosp_2019_04_4.

Burford, R. L.-Katz, J. L. [1977]: Input-Output Multipliers Without a Full Input-Output Matrix. Proceedings of Business and Economics. American Statistical Association, Chicago, 453-458. o.

Burford, R. L.-Katz, J. L. [1981]: A Method for the Estimation of Input-Output Type Multipliers when no Input-Output Model Exists. Journal of Regional Science, Vol. 21. No. 2. 151-162. o. https://doi.org/10.1111/j.1467-9787.1981.tb00691.x.

CROMPton, J. L.-McKaY, S. L. [1994]: Measuring the economic impact of festivals and events: some myths, misapplications and ethical dilemmas. Festival Management and Event Tourism, Vol. 2. No. 1. 33-43. o. https://doi.org/10.3727/106527094792335782.

Diedering, M.-Kwiatkowski, G. [2015]: Economic impact of events and festivals on host regions. Methods in practice and pontential sources of bias. Polish Journal of Sport and Tourism, Vol. 22. No. 4. 247-252. o. https://doi.org/10.1515/pjst-2015-0033. 
Dietzenbacher, E.-Lahr, M. L. [2013]: Expanding Extractions. Economic Systems Research, Vol. 25. No. 3. 341-360. o. https://doi.org/10.1080/09535314.2013.774266.

DWyer, L.-JAGO, L.-Forsyth, P. [2016]: Economic evaluation of special events: Reconciling economic impact and cost-benefit analysis. Scandinavian Journal of Hospitality and Tourism, Vol. 16. No. 2. 115-129. o. https://doi.org/10.1080/15022250.2015.1116404.

EU [2013]: Az Európai Parlament és a Tanács 549/2013/EU rendelete (2013. május 21.) az európai unióbeli nemzeti és regionális számlák európai rendszeréről. Az Európai Unió Hivatalos Lapja, 56. évf. június 26. https://eur-lex.europa.eu/legal-content/HU/TXT/HTML/? uri=CELEX:32013R0549\&from $=$ HU.

Fesztiválkutatás [2016]: Fesztiválkutatás 2016. Örökség Kultúrpolitikai Intézet, Budapest, http://oroksegintezet.hu/images/kutatas/fesztkut_web.pdf.

Flegg, A. T.-Webber, C. D.-Elliot, M. V. [1995]: On the Appropriate Use of Location Quotients in Generating Input-Output Tables. Regional Studies, Vol. 29. No. 6. 547-561. o. https://doi.org/10.1080/00343409512331349173.

Formádi Katalin-Hunyadi Zsuzsanna [2019]: Helyi büszkeség vagy bosszúság? A fesztiválok hatása a települések életében. Prosperitas, 6. évf. 4. sz. 95-111. o. http://dx.doi. org/10.31570/Prosp_2019_04_6.

Getz, D. [2005]: Event Management and Event Tourism. Cognizant Communication Corporation, New York.

Getz, D. [2010]: The Nature and Scope of Festival Studies. International Journal of Event Management Research, Vol. 5. No. 1. 1-47. o.

Greig, M. A. [1971]: The Regional Income and Employment Multiplier Effects of a Pulp Mill and Paper Mill. Scottish Journal of Political Economy, Vol. 18. 31-48. o. https://doi. org/10.1111/j.1467-9485.1971.tb00972.x.

Harrigan, F. J. [1982]: The Estimation of Input-Output Type Output Multipliers when no Input-Output Model Exists: A Comment. Journal of Regional Science, Vol. 22. No. 3. 375-381. o. https://doi.org/10.1111/j.1467-9787.1982.tb00762.x.

IndRa DÁnIEL [2009]: A Balaton Sound és a VOLT Fesztivál gazdasági hatásvizsgálata. Turizmus Bulletin, 13. évf. 3. sz. 31-34. o. https://mtu.gov.hu/documents/prod/Bulletin2009_3.pdf.

Jackson, J.-Houghton, M.-Russell, R.-Triandos, P. [2005]: Innovations in Measuring Economic Impacts of Regional Festivals: A Do-It-Yourself Kit. Journal of Travel Research, Vol. 43. No. 4. 360-367. o. https://doi.org/10.1177/0047287505274649.

Kiм, J.-Boo, S.-Kiм, Y. [2013]: Patterns and trends in event tourism study topics over 30 years. International Journal of Event and Festival Management, Vol. 4. No. 1. 66-83. o. https://doi.org/10.1108/17582951311307520.

Koopmans, C.-Oosterhaven, J. [2011]: SCGE modelling in cost-benefit analys: The Ductch experience. Research in Transportation Economics, Vol. 31. No. 1. 29-36. o. https://doi. org/10.1016/j.retrec.2010.11.005.

KoppÁNY KRISZTIÁN [2016]: Betegek terápiás preferenciáinak feltárása és ellátásának javítása conjoint analízissel és költség-haszon elemzéssel. Prosperitas, 3. évf. 1. sz. 33-56. o.

Koppány KRIszTián [2017a]: Makrogazdasági és regionális hatáselemzés multiplikátormodellekkel. Hazai alkalmazásokkal és számpéldákkal, Excel környezetben. Széchenyi István Egyetem, Győr.

Koppány Krisztián [2017b]: A növekedés lehetőségei és kockázatai. Magyarország feldolgozóipari exportteljesítményének és ágazati szerkezetének vizsgálata, 2010-2014. Közgazdasági Szemle, 64. évf. 1. sz. 17-53. o. https://doi.org/10.18414/ksz.2017.1.17. 
Koppány Krisztián [2018a]: Mennyit termel egy fesztivál valójában? A fesztiválok hatáselemző modellje. Magyar Fesztiválszövetség szezon- és évadzáró konferencia, Budapest, november 19.

KoppÁNy KRISZTiÁN [2018b]: Mi lenne velünk az autóipar nélkül? Ágazataink nemzetgazdasági jelentőségének vizsgálata input-output táblákkal és hypothetical extractions módszerrel. Szigma, 49. évf. 1-2. sz. 11-38. o.

KoppáNy KRISZTián [2019]: Gazdasági hatásvizsgálatok módszertani kérdései. Az EFOP-3.6.116-2016-00012 kódszámú, Innovatív megoldásokkal Zala megye $\mathrm{K}+\mathrm{F}+\mathrm{I}$ tevékenysége hatékonyságának növeléséért című projekt zárókonferenciája, Győr, március 19-20.

KoppáNy KRISZTiÁN-STESZli ÁdÁM [2017]: Egy járműipari vállalat tovagyűrűző gazdasági hatásainak elemzése a SZEconomy modellben. Plenáris előadás. Kautz Konferencia 2017, Sport - Gazdaság - Turizmus, Széchenyi István Egyetem, június 8.

KSH [2018a]: A háztartások fogyasztása. Statisztikai Tükör, május 30. Központi Statisztikai Hivatal, Budapest.

KSH [2018b]: Tájékoztatási adatbázis. Központi Statisztikai Hivatal, Budapest, http://statinfo. ksh.hu/Statinfo/.

Kundi VIKTóRIA [2012]: Fesztiválok gazdasági hatásmérésére alkalmazott nemzetközi és hazai modellek bemutatása. Tér és Társadalom, 26. évf. 4. sz. 93-110. o. https://doi.org/10. 17649/tet.26.4.2080.

KUNDI VIKTóRIA [2013]: Fesztiválok városokra gyakorolt gazdasági és társadalmi-kulturális hatásainak elemzése. Doktori disszertáció. Széchenyi István Egyetem, Győr.

Lenzen, M.-Benrimoj, C.-Kotic, B. [2010]: Input-Output Analysis For Business Planning: A Case Study of the University of Sydney. Economic Systems Research, Vol. 22. No. 2. 155-179. o. https://doi.org/10.1080/09535314.2010.484012.

Libor Anita-Kocsis Krisztina [2018]: A jegy 55-szörösére, a költségvetés 330-szorosára nőtt a Szigeten. Index, augusztus 12. https://index.hu/kultur/zene/2018/08/12/25_ev_alatt_ otvenotszorosere_dragult_a_sziget/.

MARnitz István [2019]: Kevesebb Sziget-lakó, szerényebb nyereség. Népszava, augusztus 14. https://nepszava.hu/3046500_kevesebb-sziget-lako-szerenyebb-nyereseg.

MFSZ [2017]: A fesztiválpiac jellemzői. Magyar Fesztivál Szövetség, Budapest, http://www. fesztivalregisztracio.hu/download/fesztpiac_2014-2017.pdf.

MFSZ [2019]: A regisztrált fesztiválok jellemzői a 2019. novemberi adatok alapján. Magyar Fesztivál Regisztrációs és Minősítési Program, Magyar Fesztiválszövetség, http://fesztival regisztracio.hu/index.php? modul $=\mathrm{cms} \&$ page $=$ statisztika.

Miller, R. E.-Blair, P. D. [2012]: Input-Output Analysis. Foundations and Extensions. Second Edition. Cambridge University Press, Cambridge, https://doi.org/10.1017/cbo9780511626982. MTÜ [2017]: Nemzeti Turizmusfejlesztési Stratégia. Magyar Turisztikai Ügynökség, https:// mtu.gov.hu/documents/prod/mtu_strategia_2030.pdf.

Polenske, K. R. [1997]: Linked system of enterprise, regional and national input-output accounts for policy analysis. Megjelent: Chatterji, M. (szerk.): Regional Science: Perspectives for the Future. Macmillan Press, Houndmills, Basingstoke, 26-42. o. https://doi. org/10.1007/978-1-349-25514-6_3.

Porter, P. K.-Chin, D. M. [2012]: Economic impact of sport events. Megjelent: Maennig, W.Woods, R. A. (szerk.): International Handbook on the Economics of Mega Sport Events. Edvard Elgar, 246-269. o. https://doi.org/10.4337/9780857930279.00023.

RÉvÉsz TAMÁs [2001a]: A turizmus költséghatás-elemzése SAM-modellel. Statisztikai Szemle, 80. évf. 10-11. sz. 825-847. o. 
RÉvÉSz TAMÁs [2001b]: Költségvetési és környezetpolitikák elemzése általános egyensúlyi modellekkel. PhD-értekezés. Budapesti Közgazdaságtudományi Egyetem, http://phd.lib. uni-corvinus.hu/1085/13/Revesz_Tamas_dhu.pdf.

RÉvÉSz TAMÁs-Koppány KRISZTiÁn [2018]: A nemzetgazdasági modellekben szereplő mátrixok kétirányú kiigazító módszereiről. Szigma, 49. évf. 3-4 sz. 139-172. o.

Solt Katalin-TaKács Dávid [2015]: A költség-haszon elemzés alkalmazása önkéntes programokra. Prosperitas, 2. évf. 2. sz. 46-59. o.

Solt Katalin-Koppány Krisztián-Hunyadi Zsuzsanna [2018]: Csináljuk a fesztivált! Hogyan hatnak a fesztiválok a nemzetgazdaság teljesítményére? Plenáris előadás, Kulturális gazdaság. Széchenyi István Egyetem Kautz Gyula Gazdaságtudományi Kar, Kautz Gyula Emlékkonferencia, Győr, június 5.

Solt Katalin-Koppány Krisztián-Hunyadi Zsuzsanna [2019]: Mennyivel járulhatnak hozzá a fesztiválok a gazdaság teljesítményéhez? Módszertani megközelítések és gyakorlati alkalmazás. Tér-Gazdaság-Ember, 7. évf. 2-3. sz. 75-102. o.

Sulyok Judit [2010]: A magyar lakosság fesztivállátogatási szokásai. Turizmus Bulletin, 14. évf. 3. sz. 2-11. o.

SULYOK JUDIT [2016]: A magyarországi fesztiválturizmus országos szintű marketingje. Megjelent: Jászberényi Melinda-Zátori Anita-Ásványi Katalin (szerk.): Fesztiválturizmus. Akadémiai Kiadó, Budapest.

SzABó Norbert [2015]: A regionális input-output táblák becslési módszerei. Területi Statisztika, 55. évf. 1. sz. 3-27. o. http://www.ksh.hu/docs/hun/xftp/terstat/2015/01/szabo.pdf.

Tiebout, C. M. [1967]: Input-output and the firm: a technique for using national and regional tables. Review of Economics and Statistics, Vol. 49. 260-262. o.

U1 Nonprofit [2019]: Tömegszámlálás kültéri nagyrendezvényeken. Kutatási jelentés, az EFOP-3.6.1-16-2016-00012 kódszámú, Innovatív megoldásokkal Zala megye K+F+I tevékenysége hatékonyságának növeléséért című projekt. U1 Nonprofit Kft.

Wilson, J.-Arshed, N.-Shaw, E.-Pret, T. [2017]: Expanding the domain of festival research: A review and research agenda. International Journal of Management Reviews, Vol. 19. No. 2. 195-213. o. https://doi.org/10.1111/ijmr.12093.

ZALAI ERNő [2012]: Matematikai közgazdaságtan II. Többszektoros modellek és makrogazdasági elemzések. Akadémiai Kiadó, Budapest.

\section{Függelék}

\section{A számitások módszertana}

Az országos hozzáadottérték-, munkajövedelem- és foglalkoztatási multiplikátorokat a KSH 2018. évi módszertan (KSH [2018a]) szerinti 2015. évi, szervezet $\times$ szervezet típusú, hazai kibocsátásra közölt ágazati kapcsolatok mérlege alapján számítottuk, rendre a következő formulák alapján: $\langle\mathbf{v}\rangle(\mathbf{I}-\mathbf{A})^{-1},\langle\mathbf{h}\rangle(\mathbf{I}-\mathbf{A})^{-1}$ és $\langle\mathbf{e}\rangle(\mathbf{I}-\mathbf{A})^{-1}$, ahol $\mathbf{v}$ az ágazati hozzáadottérték-hányadok, $\mathbf{h}$ a munkajövedelem-hányadok és e az ágazati foglalkoztatási intenzitások (ezer fö/millió forint) vektora, A a közvetlen ráfordítási együtthatók mátrixa, I pedig az egységmátrix. A $\langle>$ zárójelek a diagonálismátrix-képzés, a -1 kitevő pedig a mátrixinvertálás müveletét jelöli. 
A regionális multiplikátorokat ugyanezen formuláknak a fesztivál gazdamegyéjének interregionális input-output táblára történő alkalmazásával határoztuk meg.

A regionális táblázatok előállításának lépései az alábbiak voltak. Elsőként az országos ÁKM-et hoztuk a megyei statisztikáknak megfelelő aggregáltsági szintre. Míg az országos input-output táblák a gazdaság szerkezetét 65 ágazatra bontva mutatják, a megyei szintű statisztikák ilyen mély felbontást nem alkalmaznak, csupán 11 összevont ágazattal dolgoznak. Ezek a következők: A Mezőgazdaság; B-D-E Energia- és hulladékipar; C Feldolgozóipar; F Építőipar; G-H-I Kereskedelem, szállítás, vendéglátás; J Információ, kommunikáció; K Pénzügyi, biztosítási tevékenység; L Ingatlanügyletek; M-N Szakmai, tudományos tevékenység; O-P-Q Közigazgatás, oktatás, egészségügy; R-S-T-U Müvészet, szórakoztatás, szabadidő. A területi bontásért cserébe a gazdaság ágazati sokszínűsége terén jelentős áldozatokat kell tehát hoznunk. A megyei szintü ágazati hatások és multiplikátorok jóval elnagyoltabb, pontatlanabb formában fejezhetők ki. A 11 ágazatra összevont táblázatokat úgynevezett aggregáló mátirxok segítségével állítottuk elö a $65 \times 65$ ágazatos országos ÁKM-ekből. Az így kapott, 11 × 11 ágazatos országos input-output táblákból indultunk ki a megyei táblázatok előállítása során.

A megyei táblázatok peremadataira vonatkozóan meglehetősen korlátozottan állnak rendelkezésre statisztikai információk. A nemzeti számlákkal és az ÁKM-ekkel konzisztens módon kizárólag a területi (megyei) hozzáadott értékeket és munkajövedelmeket találjuk meg a KSH legrészletesebb publikációs felületén, a Tájékoztatási adatbázisban, amelyeket kereszttáblázatokba rendeztünk (KSH [2018b]).

Az input-output táblák legszélső peremeire, az ágazati kibocsátások értékére a statisztikai hivatal megyei szinten egyáltalán nem közöl adatot. Ezeket legfeljebb becsléssel tudjuk elöállítani. Itt az egyik leggyakrabban alkalmazott feltételezés, hogy az ágazatok hozzáadott érték/kibocsátás arányai az ország minden megyéjében azonosak az országossal. Ezt feltéve, a megyei ágazati bruttó hozzáadott értékre (Gross Value Added, GVA) vonatkozó adatokból vissza tudjuk számolni a megyék egyes ágazatainak becsült kibocsátási értékét.

A megyeiágazatokban foglalkoztatottak számát hasonlóképpen becsülhetjük a megyei ágazati munkavállalói jövedelmek és az egyes szektorok országos egy före jutó munkavállalói jövedelmeinek hányadosaként. E mögött természetesen az a feltételezés áll, hogy az egyes ágazatokban dolgozók átlagjövedelme minden megyében egyforma.

Az adott megye ágazatainak, valamint Magyarország más régióinak ágazati hozzáadott értékét, munkajövedelmét, foglalkoztatotti létszámát és kibocsátását a fentiek szerint határoztuk meg, és az interregionális input-output tábla alsó szárnyába rendeztük. Az alsó szárny kibocsátási peremének transzponáltja adja a regionális ÁKM sorok szerinti összesen értékeit, amelyeket az import és a nettó termékadók, valamint az összes felhasználás, a bruttó hozzáadott érték, a munkajövedelmek és a kibocsátás országos értékével kiegészítve, megkapjuk a teljes táblázat jobb oldali peremét.

A termékadók és az import egyes megyei ágazatokra és szektorokra vonatkozó értékét az országos ágazati, illetve szektorális termékadó/összes felhasználás, illetve import/összes felhasználás arányok alapján származtattuk. 
Az egyes megyék interregionális input-output tábláit a beszállító és vevő ágazatok regionális specializációja mellett a régió relatív méretét is figyelembe vevő Flegg-féle lokációs hányadosok (Flegg és szerzötársai [1995]) alkalmazásával becsültük:

$F L Q_{i j}^{r}=\lambda^{r} C L I Q_{i j}^{r}$,

ahol $r$ az egyes régiókat, $i$ és $j$ az egyes ágazatokat jelöli;

$C I L Q_{i j}^{r}=\frac{x_{i}^{r} / x_{i}^{n}}{x_{j}^{r} / x_{j}^{n}}, \quad$ ha $\quad i \neq j, \quad$ és $\quad C I L Q_{i j}^{r}=\frac{x_{i}^{r} / x_{i}^{n}}{x^{r} / x^{n}}, \quad$ ha $\quad i=j$;

$\lambda^{r}=\left\{\log _{2}\left[1+x^{r} / x^{n}\right]\right\}^{\delta}$

a régió relatív méretét kifejező korrekciós szorzó $0 \leq \delta<1$ érzékenységi paraméterrel, ahol $x^{r}$ a megyei, $x^{n}$ pedig az országos munkajövedelmek. Az FLQ lokációs hányadosokat az $a_{i j}^{r r}=a_{i j} \min \left(F L Q_{i j}^{r}, 1\right)$ szerint használhatjuk az országos input-output tábla $a_{i j}$ közvetlen ráfordítási együtthatóinak módosítására, ahol $a_{i j}^{r r}$ az intraregionális koefficienseket jelöli.

A belső négyzet és a háztartási fogyasztás oszlopokhoz tartozó elemek meghatározásához a fentiek szerinti Flegg-féle lokációs hányadosokat és kiterjesztett lokációs hányados (LQ) módszert használtunk, amely az interregionális kereskedelem értékeit maradékelven, az alábbi képlet szerinti koefficiensek segítségével határozza meg: $a_{i j}^{s r}=a_{i j}\left[1-\min \left(F L Q_{i j}^{r}, 1\right)\right]$.

A szakirodalmi ajánlásoknak megfelelően a $\delta$ paraméter értékét 0,3 -nek választottuk, a lokációs hányados intraregionális kapcsolatoknál figyelembe vett maximális értékét viszont nem 1-ben, hanem 0,99-ban határoztuk meg, ami azt jelenti, hogy még ha az ágazat megyei koncentrációja az országost meg is haladja, a beszállítások legalább 1 százaléka ekkor is régión kívülröl érkezik.

A háztartások fogyasztását megbontottuk az adott megye és más hazai régiók háztartásainak fogyasztására. Az összes fogyasztást az adott terület összes munkajövedelmének országos munkajövedelemhez viszonyított aránya és az országos fogyasztási kiadás szorzataként becsültük.

Az egyéb hazai végső felhasználás és export oszlopainál az adott ágazat országos egyéb hazai végső felhasználás/kibocsátás, illetve export/kibocsátás arányait felhasználva generáltuk a kiinduló táblázatelemeket.

A kapott táblázatelemeket azért hívhatjuk csupán kiindulónak, mert ezek esetén az input-output táblák alapvető könyvelési azonossága, miszerint az oszlop- és a sorösszegek megegyeznek, még nem (feltétlenül) teljesül. Szükséges a táblázat úgynevezett kiegyensúlyozása, a kiinduló elemek belső arányait legjobban megőrző módon az ismert, illetve becsült folyó termelö- és végfelhasználási (oszlopösszegek), valamint kibocsátási, nettó termékadó és import (sorösszegek) peremadatokra történő ráfeszítése. A táblázatok kiegyensúlyozását úgynevezett additív RAS eljárással (lásd Révész [2001b], Révész-Koppány [2018]) végeztük. 